\title{
Rice Improvement Through Genome-Based Functional Analysis and Molecular Breeding in India
}

Pinky Agarwal ${ }^{1 \dagger}$, Swarup K. Parida ${ }^{1 \dagger}$, Saurabh Raghuvanshi $^{2}$, Sanjay Kapoor ${ }^{2}$, Paramjit Khurana ${ }^{2}$, Jitendra P. Khurana ${ }^{2}$ and Akhilesh K. Tyagi ${ }^{1,2^{*}}$

\begin{abstract}
Rice is one of the main pillars of food security in India. Its improvement for higher yield in sustainable agriculture system is also vital to provide energy and nutritional needs of growing world population, expected to reach more than 9 billion by 2050. The high quality genome sequence of rice has provided a rich resource to mine information about diversity of genes and alleles which can contribute to improvement of useful agronomic traits. Defining the function of each gene and regulatory element of rice remains a challenge for the rice community in the coming years. Subsequent to participation in IRGSP, India has continued to contribute in the areas of diversity analysis, transcriptomics, functional genomics, marker development, QTL mapping and molecular breeding, through national and multi-national research programs. These efforts have helped generate resources for rice improvement, some of which have already been deployed to mitigate loss due to environmental stress and pathogens. With renewed efforts, Indian researchers are making new strides, along with the international scientific community, in both basic research and realization of its translational impact.
\end{abstract}

Keywords: Gene function, Genome, India, Marker-assisted selection, Rice, Oryza sativa, Transcriptomics

\section{Introduction}

Rice feeds a large part of the world's population, including Indians, and hence is an extremely important cereal crop. Sustained efforts have been made to improve its yield to meet the ever-increasing global demand. This has been possible largely through studies carried out on its agronomy, physiology, genetics and molecular biology. Since the genome sequence of an organism opens up new vistas to improve its performance, multiple efforts were simultaneously made to sequence indica and japonica subspecies of rice (Oryza sativa) genomes culminating in the availability of a map-based sequence of the genome from rice (International Rice Genome Sequencing Project 2005; reviewed in Vij et al. 2006). To this international initiative, India contributed by

\footnotetext{
*Correspondence: akhilesh@genomeindia.org

'Equal contributors

${ }^{1}$ National Institute of Plant Genome Research (NIPGR), Aruna Asaf Ali Marg, New Delhi 110067, India

${ }^{2}$ Interdisciplinary Centre for Plant Genomics and Department of Plant Molecular Biology, University of Delhi, South Campus, New Delhi 110021, India
}

sequencing and assembly of the long arm of chromosome 11 and participation in mapping/annotation of the rice genome. This was achieved by the collaborative efforts of the researchers at the Department of Plant Molecular Biology, University of Delhi, South Campus, and National Research Center on Plant Biotechnology, Indian Council of Agricultural Research (Chen et al. 2002; International Rice Genome Sequencing Project 2005; The Rice Chromosomes 11 and 12 Sequencing Consortia 2005; Rice Annotation Project 2007, 2008). Recently, remarkable progress has been made in understanding genetic and functional diversity in rice by sequencing Oryza glaberrima (Wang et al. 2014) and 3000 other globally distributed accessions of rice (Li et al. 2014).

An annotated genome enlists the putative genes and their sequence catalogs. Subsequently, the encoded proteins by such genes can be classified into families depending on the presence of a conserved domain or motif. Once the locus IDs of genes are delineated, gene organization and structure can be analyzed, to determine

\section{Springer}


unique features of genes and their products. Similarly, evolutionary and phylogenetic analyses help classify the family members into distinct classes and define their origin. Hence, the availability of the annotated rice genome has paved the way for the identification of members of multifarious gene families, India being a major contributor to this analysis. Many of these have been linked with the Rice Genome Annotation Project (RGAP) and are available at the community annotation project, while others are yet to be added (http://rice.plantbiology.m su.edu/annotation_community_families.shtml).

The next imperative step is to gain knowledge about the expression patterns of genes (Agarwal et al. 2014). For this, techniques like microarrays, RNA sequencing, microRNA sequencing and downstream analyses have been used to study transcriptomes, and their regulation by miRNA in multifarious developmental and stress conditions related to rice. Differentially regulated genes have been selected as targets for functional validation with the eventual aim to raise improved rice plants. This has been accomplished by generating transgenic plants with altered expression of the genes, followed by their detailed analysis. In this way, Indian researchers have been able to identify genes involved in development and stress response and elucidate downstream genes and pathways. For the larger benefit of the scientific community, the data generated has been deposited in international public repositories. To this effect, databases as well as bioinformatic tools are being created to facilitate easy access and seamless analysis of large data sets.

Both annotated genes and intergenic regions can be used to define functions of genes/quantitative trait loci (QTLs) by forward genetic approaches. Indian labs are making use of rich diversity of the rice genome for such purposes. The available genome/transcriptome sequences of diverse rice genotypes have been used to generate enormous resources in the form of genomic (genic) SSR (simple sequence repeat) and SNP (single nucleotide polymorphism) markers at a genome-wide scale especially in indica and aromatic rice (Parida et al. 2009; Jain et al. 2014). The large-scale validation and high-throughput genotyping of these genome/ gene-based markers in diverse natural Indian germplasm (core and mini-core) collections, advanced generation mapping and mutant populations of rice are underway. These efforts assisted in mining of novel natural/functional allelic variants, understanding of molecular diversity and domestication pattern, construction of high-density genetic linkage maps and apply genetic/association mapping to identify potential genomic loci associated with complex quantitative traits of agronomic importance in rice (Sharma et al. 2005; Ngangkham et al. 2010; Marathi et al. 2012; Kumar et al. 2015). Marker-assisted selection (MAS) to introgress and pyramid superior functional genes (alleles)/QTLs regulating complex yield/quality component and stress tolerance traits into diverse Indian rice genotypes for their genetic enhancement has been attempted (Singh et al. 2011a). In this article, an attempt has been made to highlight some key investigations from India in the post-genomic era that help gain knowledge about molecular biology and genetics along with its applications to improve the rice crop. Several of these findings were also presented during the 11th International Symposium on Rice Functional Genomics held in India in 2013.

\section{Review}

\section{Loci for 3394 Genes from 50 Families Annotated}

Transcription factors (TFs) are integral components of any regulatory and/or metabolic pathway. Comprehensive genome wide analyses of their gene structure and expression have revealed interesting aspects about their regulation during development and stress and provided leads for their functional characterization. Amongst the first detailed analysis of large TF gene families, the $\mathrm{C}_{2} \mathrm{H}_{2}$ zinc-finger family, encoded by 189 ZOS genes was found to have 97 new members, including 10 previously unnannotated members. Also, new types of zinc fingers were discovered, apart from the cannonical ones. These genes were found to differentially express during reproductive development and abiotic stresses (Agarwal et al. 2007). The rice genome was found to encode for 75 MADS box TFs. Nine members belonging to the $M \beta$ group of the MADS-family, which was considered absent in monocots, were also identified (Arora et al. 2007). Eighteen new bZIP motif-encoding genes were identified, making the total to 89 genes for this class of TFs. Sixty-two genes out of 72 intron-containing genes had the intron within the bZIP region (Nijhawan et al. 2008). The analysis of homeobox gene family showed that HD-ZIP III sub family was intron-rich, resulting in a high number of alternatively spliced genes. Also, $50 \%$ of the genes had evolved due to duplication events (Jain et al. 2008c). Most of the HSFs were found to be induced by heat (Mittal et al. 2009), apart from other developmental and stress conditions. Splicing of a member resulted in the exclusion of its NES (Chauhan et al. 2011). Many DOF genes were found to be expressed during various stages of seed development (Gaur et al. 2011) and it is known that DOFs play an important role in the process (Agarwal et al. 2011). The promoters of some of the $M Y B$ genes were found to have novel cis elements and lower arms of chromosomes had relatively more MYB genes (Katiyar et al. 2012). Thus, a comprehensive analysis of members of each TF family brings to light certain unique features, which remain unnoticed during whole genome annotation. 
Besides TFs, a number of gene families coding for various signal transduction components (STCs) have also been characterized for clues to their structure-function relationships. Amongst hormone signaling pathways, 31 OsAux/IAA genes were identified and most of them were found to be up-regulated upon auxin treatment, six of them at much higher levels (Jain et al. 2006a). Another auxin responsive family, GH3, encoding amido synthetases involved in catalyzing the synthesis of IAAamino acid conjugates, was found to have 12 members in rice. Group III genes of this family are apparently absent not only in rice but other monocots too (Jain et al. 2006b). The early auxin responsive intronless gene family SAUR has 58 members, 17 of which are clustered on chromosome 9 (Jain et al. 2006d). Kinases and phosphatases are essential parts of any signaling pathway. Rice genome has been found to code for 31 CDPKs, two of which were newly identified (Ray et al. 2007). The identification protocol led to 192 and 70 previously unidentified genes as coding for RLCKs (Vij et al. 2008) and MAPKKKs, respectively (Rao et al. 2010). Most of the 11 SERK/SERLs had been previously annotated incorrectly and were found to express in tissues other than somatic embryos as well (Singla et al. 2009). Also, 173 members for three classes of LecRLKs were identified (Vaid et al. 2012). For ten CBLs, 33 interacting CIPKs were found. Many of these interactions were found to be conserved from Arabidopsis (Kanwar et al. 2014). Five families of phosphatases were found to have been encoded by 132 genes (Singh et al. 2010a). Also, 51 genes were found to code for 73 TCS proteins, including 14 histidine kinases, 5 phosphotransfer proteins and 32 response regulator encoding genes. They were found to be clustered at various regions on rice chromosomes (Pareek et al. 2006). Amongst other STCs, 687 F-box protein encoding genes were identified in rice, many of which had other domains as well (Jain et al. 2007). Another class of STCs comprises of known stress inducible genes. Rice genome was found to have 18 abiotic stress inducible SAP genes (Vij and Tyagi 2006), heat stress and other abiotic stress inducible 23 sHsps (Sarkar et al. 2009) and only five Hsp100 genes (Batra et al. 2007). Jproteins are co-chaperones to Hsp70 and rice has 104 such genes, coding for proteins with high molecular weights. Five such genes could even rescue the corresponding yeast mutant under heat stress (Sarkar et al. 2013). Amongst transporters, rice genome was found to code for 33 calcium transporters, which included one channel, 14/15 ATPases and 16 exchangers (Goel et al. 2011; Kamrul Huda et al. 2013), 133 ABC transporters (Saha et al. 2015) and 14 sulphate transporters. The sulphate transporters are expressed during sulphate starvation, heavy metal and abiotic stress as well as reproductive development (Kumar et al. 2011). Apart from these, phospholipase $\mathrm{A}$ and $\mathrm{C}$ components have also been identified from rice genome (Singh et al. 2013a; Singh et al. 2012a).

The identification of genes encoding transcriptional regulators in rice has its share of contribution from India. In effect, eight, 19 and five genes coding for Dicer-like proteins, Argonautes and RNA-dependent RNA polymerases have been identified (Kapoor et al. 2008). Apart from this, 115 RNA helicases and 31 DNA helicases have also been identified (Umate et al. 2010). Rice genome has been found to code for 51 Mediator complex protein coding genes, which include all subunits identified so far in various organisms (Mathur et al. 2011). Eleven regulators belonging to various families have the KIX domain, which is responsible for protein-protein interactions (Thakur et al. 2013). Gene family analysis often brings out interesting aspects of the genome. A pair of chymotrypsin protease inhibitor encoding genes, out of a total of 17 , shares a bidirectional promoter (Singh et al. 2009). Also, genes coding for an assortment of other proteins have been identified. This includes 48 genes coding for the enzyme glutaredoxin (Garg et al. 2010), 11 for peroxiredoxins (Umate 2010), 14 for lipoxygenase (Umate 2011; Marla and Singh 2012), 11 for Class I metallothioneins induced under heavy metal stress (Gautam et al. 2012), 28 for cyclophilins (Trivedi et al. 2012), 14 for glyoxalases I and II (Mustafiz et al. 2011), 16 carotenoid biosynthesis genes (Chaudhary et al. 2010) and 158 ARMADILLO genes, which have an ARM repeat (Sharma et al. 2014a). Fifty-nine CBS domain containing proteins have also been found to contain other domains, and hence may perform diverse functions (Kushwaha et al. 2009). Thus, in totality, locus IDs have been assigned to the members of several important gene families along with insights into their expression profiles during development and abiotic stress conditions. Also, the interacting partners and/or promoter sequences have been analyzed for a few members. The general points of interest include (i) possibility of identifying new genes and clades for a family on the basis of molecular model-based comparisons, (ii) conservation in position of introns, (iii) compensating evolutionary selection of mutations in protein structure (iv) identification of state-specific or inducible genes of a family and (v) identification of gene functions that have evolved specifically in monocots.

\section{Databases and Tools are Being Used for Storing and Mining Information}

As more information is getting accumulated in plant biology, databases are being created to make the information publically available, for easy access and analysis. These databases have a user friendly interface for easy data retrieval (Agarwal et al. 2014). Indian rice scientists 
have developed various databases on varied aspects. For QTLs related to abiotic stress, QlicRice provides not only the genomic locations, but also the responsible locus IDs (Smita et al. 2011). STIFDB2 documents all stress responsive TFs in both indica and japonica rice. Apart from an extensive cis regulatory element analysis, it can be used for network prediction as well (Naika et al. 2013). Similarly, RiceSRTFDB has records of stress-responsive TFs along with their expression patterns, mutants and cis element analysis (Priya and Jain 2013).

A new concept for literature based 'Manually Curated Database of Rice Proteins' has been developed based on novel data curation methods that enable digitization and semantic integration of experimental data. The current release of database has data of 2401 rice proteins manually curated from 538 research articles. Over 800 phenotypic/biochemical traits have been curated along with their associated genes (Gour et al. 2014). The availability of the genome sequence allows researchers to perform multiple analysis, such as elucidation of intronless genes (Jain et al. 2008a) and prediction of miRNA targets (Archak and Nagaraju 2007). Various tools have been developed and validated using rice genome sequence, such as RetroPred for prediction of non-LTR retrotransposons (Naik et al. 2008), a machine learning tool to predict infection by rice blast fungus depending on the weather conditions (Kaundal et al. 2006), MirtronPred to predict plant mirtrons (Joshi et al. 2012) and pTAREF for prediction of miRNA targets (Jha and Shankar 2011). The URLs for all the webservers and softwares have been mentioned in Table 1.

\section{Transcriptome Analysis Presents a Snapshot of Participating Genes}

Prior to the advent of microarray and RNA seq, other strategies including subtractive hybridization were used to determine the transcript levels of multiple genes (Agarwal et al. 2014). After the sequences of rice BAC and PAC clones were available, genes were identified from drought-stressed ESTs, some of which were novel (Babu et al. 2002; Gorantla et al. 2007; Reddy et al. 2002). In order to identify genes responsible for salt tolerance, subtractive cDNA libraries have been compared between tolerant (Pokkali) and susceptible (IR64) genotypes (Kumari et al. 2009). The samples that have undergone transcriptome analysis till date fall into various categories. Multiple developmental stages, tissues subjected to a/biotic or nutrient stress, developmental stages under stress, and resistant genotypes have been used to elucidate various genes/pathways operating in the desired situation. We have performed microarray analysis on 19 stages of rice development, including both vegetative and reproductive phases, and the data have been deposited at the Gene Expression Omnibus of NCBI. Along with this, microarray data from three stages of abiotic stresses, namely, cold, dehydration and salt, have also been deposited (Agarwal et al. 2007; Arora et al. 2007; Ray et al. 2011; Sharma et al. 2012). Also, the transcriptome dynamics during entire anther development from pre-pollen mother cell stage to mature anthers with tri-nucleate pollen have been analyzed by using microarrays to reveal genes specifically expressing during meiosis and playing potential roles in sporophyte to gametophyte switching during male gametophyte development (Deveshwar et al. 2011). Thidiazuron

Table 1 Details of databases and web tools developed by Indian rice scientists

\begin{tabular}{|c|c|c|c|c|}
\hline $\begin{array}{l}\text { Sl. } \\
\text { no. }\end{array}$ & $\begin{array}{l}\text { Name of database/ } \\
\text { tool }\end{array}$ & URL & Information generated & Reference \\
\hline 1 & $\begin{array}{l}\text { Rice blast infection } \\
\text { prediction }\end{array}$ & $\begin{array}{l}\text { http://www.imtech.res.in/raghava/ } \\
\text { rbpred/ }\end{array}$ & $\begin{array}{l}\text { Predicts chances of rice blast infection by using weather } \\
\text { conditions as an input. }\end{array}$ & $\begin{array}{l}\text { Kaundal et al. } \\
2006\end{array}$ \\
\hline 2 & RetroPred & $\begin{array}{l}\text { http://www.juit.ac.in/attachments/ } \\
\text { RetroPred/home.html }\end{array}$ & $\begin{array}{l}\text { A downloadable tool which detects repeat regions in } \\
\text { genomic sequences and classifies them as LINEs and SINEs. }\end{array}$ & Naik et al. 2008 \\
\hline 3 & PTAREF & $\begin{array}{l}\text { http://scbb.ihbt.res.in/new/p-taref/ } \\
\text { form1.html }\end{array}$ & $\begin{array}{l}\text { A downloadable tool to predict miRNA targets in } \\
\text { transcriptome data. }\end{array}$ & $\begin{array}{l}\text { Jha and } \\
\text { Shankar } 2011\end{array}$ \\
\hline 4 & QlicRice & http://nabg.iasri.res.in:8080/qlic-rice/ & $\begin{array}{l}\text { A database of } 974 \text { abiotic stress-related QTLs connected with } \\
460 \text { locus IDs, with their physical and genetic data, which } \\
\text { can be easily queried. }\end{array}$ & $\begin{array}{l}\text { Smita et al. } \\
2011\end{array}$ \\
\hline 5 & MirtronPred & $\begin{array}{l}\text { http://203.92.44.117/mirtronPred/ } \\
\text { prediction.php }\end{array}$ & Uses intronic sequences as an input to predict mirtrons. & $\begin{array}{l}\text { Joshi et al. } \\
2012\end{array}$ \\
\hline 6 & STIFDB2 & http://caps.ncbs.res.in/stifdb2/ & $\begin{array}{l}\text { Encompasses over } 5000 \text { stress responsive genes from } \\
\text { Arabidopsis and both indica and japonica rice, with a } \\
\text { list of putative TF binding sites in their promoters. }\end{array}$ & $\begin{array}{l}\text { Naika et al. } \\
2013\end{array}$ \\
\hline 7 & RiceSRTFDB & $\begin{array}{l}\text { http://www.nipgr.res.in/ } \\
\text { RiceSRTFDB.html }\end{array}$ & $\begin{array}{l}\text { Salt and drought stress-responsive TFs from } 99 \text { Affymetrix } \\
\text { chips can be queried. }\end{array}$ & $\begin{array}{l}\text { Priya and Jain } \\
2013\end{array}$ \\
\hline 8 & MCDRP & $\begin{array}{l}\text { http://www.genomeindia.org/ } \\
\text { biocuration/ }\end{array}$ & $\begin{array}{l}\text { Manually curated data from all published rice genes, } \\
\text { including ontology, functions, pathways and interactions. }\end{array}$ & $\begin{array}{l}\text { Gour et al. } \\
2014\end{array}$ \\
\hline
\end{tabular}


treated rice callus has also been analyzed by microarray to identify genes related to differentiation (Chakrabarty et al. 2009). The gene expression analysis of rice roots subjected to heavy metal stress helped in the identification of genes that can be modulated for detoxification (Dubey et al. 2010; Dubey et al. 2014). In different studies, microarray analyses have been performed on root, leaf and panicle under drought stress (Smita et al. 2013) and on two contrasting genotypes under drought stress (Lenka et al. 2011), rice samples subjected to heat and/ or oxidative stresses (Mittal et al. 2012a, 2012b) and heat stress followed by recovery (Sarkar et al. 2014). With respect to biotic stress, microarray has been done for Xanthomonas infected rice plants (Grewal et al. 2012). Amongst nutrient stress, microarray analysis of calcium and phosphate starved plants shows involvement of various biosynthetic pathway genes such as carbohydrate, phosphate, lipid and nitrogen metabolism (Shankar et al. 2013; Shankar et al. 2014). Thus, whole genome transcriptome analyses have been done for diverse abiotic and biotic stress situations and various developmental stages in rice and they have helped in delineating essential genes and the associated pathways. These high quality transcriptome analyses have added to the efforts of the international community of rice researchers in generating an indispensible resource for future studies.

\section{Applications of Genome Sequencing for Functional and Regulatory Aspects}

There are many scientific groups in India working on understanding regulation of various aspects of rice development and stress responses; they have been able to pin point the specific function of important genes by raising and analyzing transgenic plants with modified expression patterns. RFL, a rice ortholog of $L E A F Y$ from Arabidopsis, controls flowering time and architecture (Deshpande et al. 2015; Rao et al. 2008; Table 2). Further, transcriptome analysis of rice plants with altered expression of a desired gene by overexpression or silencing or mutation, along with phenotypic analysis, identifies the functional relevance of the gene. The downstream genes and networks can also be elucidated by such an analysis (Agarwal et al. 2014). A mutant ewst1 in Nagina22 results in enhanced water tolerance and genes related to production of osmoprotectants and secondary metabolites are up regulated in it (Lima et al. 2015). Ectopic expression of OsiSAP1 or OsSAP11 or OsRLCK53 results in up regulation of genes imparting drought tolerance (Giri et al. 2011; Dansana et al. 2014; Mukhopadhyay et al. 2004). Plants overexpressing OsMKK6 have also been analyzed by microarray, indicating the role of this gene in stress regulation (Kumar and Sinha 2014). Microarray analysis of plants with overexpression and RNAi constructs of OsMADS29 showed that the gene controls cytokinin mediated starch biosynthesis during seed development (Nayar et al. 2013). Nuclear translocation of this TF has been shown to be regulated by way of homodimerization and interaction with at least 19 other seedexpressing MADS-box proteins (Nayar et al. 2014). The gene Pi54 in Taipei309 imparts tolerance to Magnaporthea infection by activating defense responsive pathways (Gupta et al. 2012). Thus, downstream operable genes and pathways have been elucidated. This has given valuable information on various genes and their related pathways. Table 2 enlists rice genes for which transgenic plants have been made in a homologous system.

Many genes of rice have been characterized by their altered expression in a heterologous system as Arabidopsis and tobacco. Although these model plants are adopted for the ease with which the phenotype can be easily scored, in most cases, the results can be extrapolated to rice. For example, not only rice plants overexpressing OsDREB2A are abiotic stress tolerant (Mallikarjuna et al. 2011), the gene OsDREB1B confers similar phenotype in tobacco as well (Gutha and Reddy 2008). Even in the case of promoters, rice sucrose synthase1, RSs1 promoter confers phloem-specific expression in Arabidopsis (Saha et al. 2007). Such promoter sequences can be used for targeted gene expression. Ectopic expression of many abiotic stress responsive rice genes in Arabidopsis and/or tobacco makes plants tolerant to abiotic stress responses. Prominent amongst these are stress associated proteins, SAP1/11, receptorlike cytoplasmic kinase, OsRLCK253 (Giri et al. 2011), topoisomerases OsTOP6A1, OsTOP6A3 and OsTOP6B (Jain et al. 2006c, 2008b), OsTCP19 (Mukhopadhyay and Tyagi 2015), a bZIP TF in the Saltol QTL, OsHBP1b (Lakra et al. 2015), cyclin, OsCyp2-P (Kumari et al. 2014), protein phosphatase 2C, OsPP108 (Singh et al. 2015a), glutathione S-transferases, OsGSTU4 and OsGSTL2 (Sharma et al. 2014b; Kumar et al. 2013), glutaredoxin, OsGRX8 (Sharma et al. 2013), cystathionine $\beta$ synthase, OsCBSX4 (Singh et al. 2012c), Ca(2+)ATPase, OSACA6 (Kamrul Huda et al. 2014; Huda et al. 2013), metallothionein, OsMT1e-P (Kumar et al. 2012), myoinositol phosphate synthase from wild rice, PcINO1 (Patra et al. 2010; Das-Chatterjee et al. 2006; Majee et al. 2004), LEA protein, Rab16A (RoyChoudhury et al. 2007) and chymotrypsin protease inhibitor, OCPI2 (Tiwari et al. 2015b). On the biotic stress front, the promoter of CYP76M7 is Magnaporthea inducible and can be used for expression of defense related genes (Vijayan et al. 2015). OsSAP1 enhances tolerance to pathogen infection (Tyagi et al. 2014). Proteins with multiple roles have also been characterized in heterologous systems. Multidrug and toxic compound extrusion proteins, OsMATE1 and 2 have roles in both abiotic and biotic stresses and development (Tiwari et al. 2014). Germin-like protein1, OsGLP1, 
Table 2 Some rice genes and promoters analyzed to elucidate their activities in transgenic rice

\begin{tabular}{|c|c|c|c|c|c|}
\hline $\begin{array}{l}\text { Sl. } \\
\text { no. }\end{array}$ & Gene & Locus ID ${ }^{a}$ & Construct & Function & Reference \\
\hline 1 & $\begin{array}{l}\text { ANS (Anthocyanidin } \\
\text { synthase) }\end{array}$ & LOC_Os01g27490 & $\mathrm{OE}$ & $\begin{array}{l}\text { Increase in flavonoids and anthocyanins } \\
\text { and hence oxidation potential }\end{array}$ & Reddy et al. (2007) \\
\hline 2 & $\begin{array}{l}\text { ETHE1 (ETHYLMALONIC } \\
\text { ENCEPHALOPATHY } \\
\text { PROTEIN 1) }\end{array}$ & LOC_Os01g47690 & promoter & Stress and calcium responsive & Kaur et al. (2014) \\
\hline 3 & GLYOXALASEII & LOC_Os09g34100 & $\mathrm{OE}$ & Confers salt stress tolerance & $\begin{array}{l}\text { Singla-Pareek et al. } \\
\text { (2008) }\end{array}$ \\
\hline 4 & $\begin{array}{l}\text { IPK1 (inositol 1,3,4,5,6- } \\
\text { pentakisphosphate 2-kinase) }\end{array}$ & LOC_Os04g56580 & RNAi & $\begin{array}{l}\text { Silencing of IPKIdecreases the antinutrient phytic } \\
\text { acid }\end{array}$ & Ali et al. (2013a) \\
\hline 5 & $\begin{array}{l}\text { MIPS (myo-inositol-3- } \\
\text { phosphate synthase) }\end{array}$ & LOC_Os03g09250 & RNAi & $\begin{array}{l}\text { Decrease in phytate and increase in inorganic } \\
\text { phosphate and iron levels }\end{array}$ & Ali et al. (2013b) \\
\hline 6 & $\begin{array}{l}\text { NBS-Str1 (nucleotide binding } \\
\text { site-LRR) and BLEC-Str8 } \\
\text { ( } \beta \text {-lectin domain protein) }\end{array}$ & $\begin{array}{l}\text { LOC_Os02g09790 } \\
\text { and } \\
\text { LOC_Os04g01950 }\end{array}$ & Promoter & Cause increased expression under stress & Ray et al. (2012) \\
\hline 7 & $\operatorname{orfB}$ & LOC_Os12g34018 & RNAi & $\begin{array}{l}\text { Unedited mitochondrial orfB gene causes male } \\
\text { sterility by decreasing ATP synthase activity }\end{array}$ & $\begin{array}{l}\text { Chakraborty et al. } \\
(2015)\end{array}$ \\
\hline 8 & OsbHLH, OsFbox, OsiPK & $\begin{array}{l}\text { LOC_Os01g18870, } \\
\text { LOC_Os05g46050, } \\
\text { LOC_Os12g12860 }\end{array}$ & Promoter & Responsible for anther-specific expression & Khurana et al. (2013) \\
\hline 9 & OsCDR1 (aspartate protease) & LOC_Os01g08330 & $\mathrm{OE}$ & $\begin{array}{l}\text { Provides resistance against fungal and bacterial } \\
\text { pathogens }\end{array}$ & Prasad et al. (2009) \\
\hline 10 & $\begin{array}{l}\text { OsClpB-cyt (ClpB- } \\
\text { cytoplasmic /Hsp100) }\end{array}$ & LOC_Os05g44340 & Promoter & $\begin{array}{l}\text { Classical heat shock element supresses expression } \\
\text { under unstressed conditions }\end{array}$ & Singh et al. (2012b) \\
\hline 11 & OsCPK31 (CDPK) & AK110341 b & OE, RNAi & Helps in rice grain filling & $\begin{array}{l}\text { Manimaran et al. } \\
\text { (2015) }\end{array}$ \\
\hline 12 & $\begin{array}{l}\text { OsDREB2A (Dehydration- } \\
\text { responsive element binding } \\
\text { transcription factor) }\end{array}$ & LOC_Os01g07120 & OE & Osmotic, dehydration and salt stress tolerance & $\begin{array}{l}\text { Mallikarjuna et al. } \\
(2011)\end{array}$ \\
\hline 13 & OsGLP1 (germin-like protein) & LOC_Os08g35760 & RNAi & Controls plant height and disease resistance & $\begin{array}{l}\text { Banerjee and Maiti } \\
(2010)\end{array}$ \\
\hline 14 & OsGLYII-2 (GLYOXALASEII) & LOC_Os03g21460 & $\mathrm{OE}$ & Provides salinity and decarbonyl stress tolerance & Ghosh et al. (2014) \\
\hline 15 & OsGRX8 (glutaredoxin) & LOC_Os02g30850 & RNAi & Abiotic stress response & Sharma et al. (2013) \\
\hline 16 & OSIAGP (Arabinogalactan) & LOC_Os06g21410 & Promoter & Provides pollen-preferential expression & $\begin{array}{l}\text { Anand and Tyagi } \\
(2010)\end{array}$ \\
\hline 17 & OsiPA & LOC_Os10g40090 & Promoter & Confers pollen-specific expression & Swapna et al. (2011) \\
\hline 18 & OSISAP1 & LOC_Os09g31200 & $\mathrm{OE}$ & $\begin{array}{l}\text { Positively regulates water deficit stress by } \\
\text { affecting gene expression leading to loss of } \\
\text { membrane damage and lipid peroxidation }\end{array}$ & Dansana et al. (2014) \\
\hline 19 & OsISAP8 & LOC_Os06g41010 & $\mathrm{OE}$ & Abiotic stress tolerance & $\begin{array}{l}\text { Kanneganti and Gupta } \\
\text { (2008) }\end{array}$ \\
\hline 20 & $\begin{array}{l}\text { OsiWAK1 (wall associated } \\
\text { kinase) }\end{array}$ & LOC_Os11g46860 & RNAi & Plant growth and development & $\begin{array}{l}\text { Kanneganti and Gupta } \\
\text { (2011) }\end{array}$ \\
\hline 21 & OsMADS1 & LOC_Os03g11614 & $\mathrm{OE}$ & $\begin{array}{l}\text { Involved in panicle, lemma and palea } \\
\text { development }\end{array}$ & Prasad et al. (2001) \\
\hline 22 & OsMADS29 & LOC_Os02g07430 & $\begin{array}{l}\text { RNAi, OE, } \\
\text { Protein- } \\
\text { protein } \\
\text { interaction }\end{array}$ & $\begin{array}{l}\text { Regulates starch biosynthesis during seeds } \\
\text { development by regulating active cytokinin levels }\end{array}$ & $\begin{array}{l}\text { Nayar et al. (2013); } \\
\text { Nayar et al. (2014) }\end{array}$ \\
\hline 22 & OsMKK6 & LOC_Os01g32660 & $\mathrm{OE}$ & $\begin{array}{l}\text { Participates in salt stress signaling and regulates } \\
\text { phytoalexin biosynthesis due to UV exposure }\end{array}$ & $\begin{array}{l}\text { Kumar and Sinha } \\
\text { (2013); Wankhede et al. } \\
\text { (2013) }\end{array}$ \\
\hline 23 & Osoxo4 (oxalate oxidase) & LOC_Os03g48780 & $\mathrm{OE}$ & Resistance to sheath blight & Molla et al. (2013) \\
\hline 24 & OsSAG12-1 (senescence & LOC_Os01g67980 & RNAi & Negatively regulates cell death & Singh et al. (2013d) \\
\hline
\end{tabular}


Table 2 Some rice genes and promoters analyzed to elucidate their activities in transgenic rice (Continued)

\begin{tabular}{|c|c|c|c|c|c|}
\hline 25 & $\begin{array}{l}\text { OSSUV3 (SUPPRESSOR OF } \\
\text { VAR3, DNA and RNA } \\
\text { helicase, ATPase) }\end{array}$ & LOC_Os03g53500 & OE, RNAi & $\begin{array}{l}\text { Provides tolerance against salt stress by } \\
\text { upregulation of multiple hormones, resistance } \\
\text { against metal stress }\end{array}$ & $\begin{array}{l}\text { Sahoo et al. (2014a); } \\
\text { Sahoo et al. (2014b); } \\
\text { Tuteja et al. (2013) }\end{array}$ \\
\hline 26 & Pi54 & LOC_Os11g42010 & $\mathrm{OE}$ & $\begin{array}{l}\text { Provides resistance to Magnaporthea irrespective } \\
\text { of insertion position }\end{array}$ & Arora et al. (2015) \\
\hline 27 & Rab16A, 4X ABRE, 2X ABRC & LOC_Os11g26790 & Promoter & $\begin{array}{l}\text { Responsible for ABA responsive expression under } \\
\text { stress and development }\end{array}$ & Ganguly et al. (2011) \\
\hline 28 & RFL (RICE FLORICULA LEAFY) & LOC_Os04g51000 & $\begin{array}{l}\text { promoter and } \\
\text { intron }\end{array}$ & Introns have regulatory regions & Prasad et al. (2003) \\
\hline 29 & RFL (RICE FLORICULA LEAFY) & LOC_Os04g51000 & RNAi, OE & $\begin{array}{l}\text { Controls flowering, promotes axillary meristem } \\
\text { initiation and hence tillering through auxin and } \\
\text { strigolactone signaling }\end{array}$ & $\begin{array}{l}\text { Deshpande et al. } \\
\text { (2015); Rao et al. (2008) }\end{array}$ \\
\hline 30 & Ubi1 (Ubiquitin) from rice & LOC_Os06g46770 & Promoter & Confers high levels of constitutive expression & $\begin{array}{l}\text { Bhattacharyya et al. } \\
\text { (2012) }\end{array}$ \\
\hline
\end{tabular}

abased on RGAP version 7 (http://rice.plantbiology.msu.edu/)

${ }^{b}$ represents cDNA clone from KOME (http://cdna01.dna.affrc.go.jp/cgi-bin/sogo.cgi?pj=598\&class=598\&page=cDNA) as no RGAP locus ID has been found

provides tolerance to both abiotic and biotic stress (Banerjee and Maiti 2010; Banerjee et al. 2010).

Likewise, functions of few miRNAs have also been elucidated. Since miRNAs cause degradation of their target mRNAs, the two express inversely (Raghuram et al. 2014). Osa-MIR414, osa-MIR164e and osa-MIR408 have been found to regulate the expression of OsABP, OsDBH and OsDSHCT. These miRNAs are down regulated during salinity stress (Macovei and Tuteja 2012). Thus, during salt stress, miRNAs targeting DEAD box helicases are down regulated (Macovei and Tuteja 2012; Umate and Tuteja 2010). Micro RNAs are also being identified by sequencing, such as those involved in tungro virus infection and salt stress (Sanan-Mishra et al. 2009). Drought tolerant genotype, Nagina 22, shows a variety of miRNAs differentially expressed during 'anthesis' stage drought, which may be responsible for its tolerance (Kansal et al. 2015). Further, miR408 which targets several plantacyanin genes is regulated differentially in Nagina 22 as compared to drought sensitive rice variety during drought stress (Mutum et al. 2013). Another study on salt-responsive miRNA markers has highlighted the differences in miRNAs amongst a sensitive and tolerant genotype of rice (Mondal and Ganie 2014). Moreover, over half of the miRNA targets have been found to be conserved amongst indica and japonica genotypes (Archak and Nagaraju 2007). miRNAs are also responsible for low N-tolerant genotypes (Nischal et al. 2012). The antagonistic effects of arsenic and selenium are controlled by the miRNA population (Pandey et al. 2015). Also, varieties showing variance in tolerance to arsenite stress show differences in miRNA accumulation (Sharma et al. 2015). Eleven TFs, controlled by miRNAs, regulate abiotic stress responsive genes (Nigam et al. 2015). Nonconserved miRNAs have also been predicted in rice (Kumar et al. 2014). Rice has been found to have polycistronic MIR166s (Barik et al. 2014). Submergence responsive miRNA targets (Paul and Chakraborty 2013) and TF binding motifs in miRNAs (Devi et al. 2013) have been predicted. miRNA species are differentially and preferentially expressed amongst various developmental stages (Mittal et al. 2013) and callus differentiation (Chakrabarty et al. 2010). They are even responsible for the cross talk amongst biotic and abiotic stresses (Sanan-Mishra et al. 2009). The studies discussed above provide evidence how the annotation of the rice genome has been useful in determining the gene networks and also unraveling the function of genes involved in various aspects of development in rice and when it is exposed in unfavorable conditions.

\section{Genome-Wide Development and Use of Informative Genetic Markers}

The availability of gold standard reference genome sequence of japonica rice cv. Nipponbare (International Rice Genome Sequencing Project 2005) has propelled the genome resequencing and transcriptome sequencing of diverse rice genotypes in recent years by use of NGS (next-generation sequencing) approaches in India. This in turn led to the development of enormous resources in the form of genomic (genic) simple sequence repeat (SSR) and single nucleotide polymorphism (SNP) markers at a genome-wide scale in rice. Despite availability of 2240 RM (rice microsatellite) and 18,828 hyper-variable class I SSR markers from rice draft and/ or whole genome sequences (McCouch et al. 2002; International Rice Genome Sequencing Project 2005), many initiatives have been undertaken by Indian researchers to develop multiple kinds of novel conceptbased informative genomic and genic SSR markers at a genome-wide scale for expediting high-throughput genetic analysis in rice. Preliminary efforts have been made to utilize 33,722 rice unigene sequences $(48.8 \mathrm{Mb})$ for developing a novel class of non-redundant 13,230 genic 
microsatellite markers designated as UniGene derived MicroSatellite (UGMS) markers, which are bin-mapped across 12 rice chromosomes (Parida et al. 2006). Considering the added advantages of these markers in assaying allelic variation in transcribed genic sequence components of the genome, these have been placed in public domain as a web-based freely accessible relational database, $U \mathrm{~g} M$ icroSat $d b$ (Unigene $M$ icroSatellite database) for unrestricted use (Aishwarya and Sharma 2007). In another study, 17,966 novel "GNMS (genic non-coding microsatellite)" markers targeting different upstream regulatory (5'UTRs and promoters) and non-coding (3'UTRs and intronic) sequence components of protein coding genes annotated from Nipponbare rice genome were developed, which are binmapped across 12 rice chromosomes (Parida et al. 2009). This further led to the identification of 112 orthologous and paralogous "CNMS (Conserved Noncoding MicroSatellite)" markers from the putative rice promoter sequences for comparative genome mapping, and understanding of evolutionary and gene regulatory complexities among rice and other members of grass family (Parida et al. 2009). The GNMS and CNMS markers with their many desirable genetic attributes, including high polymorphic potential and functional significance have efficiency to serve as candidate gene-based microsatellite markers in diverse genomics-assisted breeding applications in rice. Subsequently, utilizing the complete rice genome sequence information, 436 well-validated HvSSR (highly variable SSR) markers with repeat-length of $51-70$ bp have been developed at a genome-wide scale (Singh et al. $2010 \mathrm{~b})$. The efficacy of these markers for exhibiting consistent PCR amplification and detecting higher allelic polymorphism among accessions even by a costeffective agarose gel, have demonstrated their suitability in large-scale genotyping applications in rice. In order to develop trait-specific genetic markers, salinity-responsive microRNAs (miRNAs) have been targeted to develop 130 miRNA-SSR markers for their efficient utilization in salinity stress tolerance markerassisted genetic enhancement of rice (Mondal and Ganie 2014). The genetic variation and evolutionary dynamics between indica cv. 93-11 and japonica cv. Nipponbare have been understood by identifying and analysing the repeat-units mutability of $\sim 50,000$ in silico polymorphic SSR markers occurring in diverse coding and non-coding sequence components of rice genome (Grover et al. 2007).

In addition to SSR markers, the whole genome resequences/pseudomolecules and transcriptomic sequences of multiple rice genotypes enabled rapid discovery and development of genomic and genic SNP and InDel (insertion-deletion) markers in silico at a genome-wide scale. Recently, an international initiative, i.e., "The 3000 rice genome sequence project" has been completed to generate 20 million SNPs by genome resequencing of 3000 rice genotypes (Alexandrov et al. 2015). Similar efforts also have been made by Indian scientists to generate genome/gene-derived SNP and InDel markers by low-coverage resequencing specifically of diverse indica genotypes, including aromatic rice. For instance, nonredundant 2495052 SNP and 324034 InDel markers have been discovered by comparing the NGS-based wholegenome resequencing data of six elite indica inbred lines (three of each cytoplasmic male sterile and restorer lines) to accelerate genomics-assisted breeding for hybrid performance in rice (Subbaiyan et al. 2012). Subsequently, the whole genome resequencing of three drought/salinity tolerant (Nagina 22 and Pokkali) and sensitive (IR64) rice accessions identified non-redundant 1784583 SNPs and 154275 InDels between reference Nipponbare and three resequenced rice accessions. Based on this outcome, genome-wide 401683 SNPs between IR64 and Pokkali and 662509 SNPs between IR64 and Nagina 22 that are well-distributed across coding and non-coding regions of these sequenced genomes were discovered with the eventual aim to deploy them in marker-assisted breeding for abiotic stress tolerance in rice (Jain et al. 2014). More recently, the comparison of whole genome resequencing data of a widely cultivated low glycemic index-containing indica rice variety, Swarna, with reference genome Nipponbare, identified 1,149,698 SNPs (65,984 non-synonymous SNPs) and 104,163 InDels for deciphering the genetic basis of complex glycemic index quantitative trait in rice (Rathinasabapathi et al. 2015).

Essentially, the genomic and genic SSR and SNP markers developed especially by Indian initiatives are amenable to large-scale validation and high-throughput genotyping at the whole genome level. These informative markers are thus suitable for multi-dimensional genomics-assisted breeding applications.

\section{Characterization of Core/Mini-Core Germplasm and Mutant Resource for Rice Genetic Enhancement}

Rice is grown in the wide range of agro-ecological conditions and adapted to diverse sociocultural traditions prevalent in India. Thus, Indian rice germplasm lines are rich in trait diversity. The rice germplasm resources, including cultivated varieties, breeding lines, landraces, wild accessions representing diverse agro-climatic regions of India as well as the world, have been conserved efficiently in different National germplasm repository centers like National Bureau of Plant Genetic Resources (NBPGR, New Delhi). The phenotypic and molecular characterization of the huge Indian rice germplasm collections is, therefore, vital in order to use the natural 
allelic diversity information in genomics-assisted rice crop improvement program. Considering the economic importance of aromatic rice in Basmati trade and commerce, significant efforts have been made for varietal identification and understanding the genetic diversity and domestication patterns majorly among different traditional (landraces) and evolved (elite) long- and short-grained Basmati and between Basmati and nonBasmati indica rice accessions (Nagaraju et al. 2002; Aggarwal et al. 2002; Sajib et al. 2012; Meti et al. 2013; Vhora et al. 2013). For example, the distinctness, uniformity and stability (DUS) in an aromatic rice variety, Pusa Basmatil, has been established by its precise phenotyping for diverse aroma and grain quality traits and large-scale genotyping of genome-wide SSR markers (Singh et al. 2004). The efficiency of genome-wide SSR markers and five mitochondrial gene-specific CAPS (cleaved amplified polymorphic sequences) markers for testing the genetic purity of Pusa6A parental lines during seed production of Pusa Rice Hybrid10 has been demonstrated. This would be of immense use in unambiguous identification and protection of rice hybrids, including marker-assisted production of pure hybrid rice seeds in India (Ngangkham et al. 2010; Anand et al. 2012). More recently, the efficacy of gene-based $50 \mathrm{~K}$ SNP chip in molecular diversity and evolutionary studies among cultivated and wild rice accessions was demonstrated (Singh et al. 2015b). The large-scale diversity analysis of Indian rice germplasm will also be useful in identifying important hot-spot (rich in trait and/or allelic diversity) rice producing regions of the country, like Eastern Indo-gangetic planes of Uttar Pradesh and Bihar for wild rice accessions as well as Eastern and North-eastern states of India for distinctive landraces (Das et al. 2013; Singh et al. 2013b, 2013c). Considering the difficulties involved in genotypic and phenotypic characterization of the huge set of available germplasm resources of rice, efforts have been made currently in India to constitute the core and mini-core collections in rice by identifying the largest amount of genetic diversity with a minimum number of accessions. In order to constitute core/minicore germplasm collections, diverse popularly grown and rarely cultivated traditional varieties and landraces belonging to indica, which constitute about $80 \%$ of total cultivated Indian rice, have been assessed for phenotypic and genotypic diversity analysis (Prashanth et al. 2002). To constitute a traitspecific mini-core in rice, diversity analysis of germplasm lines have also been performed targeting various yieldcomponent, biotic stress tolerance and grain quality traits (grain color and micronutrient content) (Banumathy et al. 2010; Singh et al. 2011a; Prasad et al. 2013; Patel et al. 2014). With the multi-institutional efforts of Indian scientists, recently a set of 98 accessions belonging to a core/ mini-core collection representing $94 \%$ allelic diversity of the total 6912 rice germplasm lines has been constituted utilizing both marker-based genotyping and phenotyping strategies and different precise statistical measures (Tiwari et al. 2015a). Similarly, a core set of 701 accessions representing $99.9 \%$ allelic diversity of total 6984 rice germplasm lines belonging to North Eastern region (considered as hot-spot region) of India has been developed (Choudhury et al. 2014). These readily available core/mini-core germplasm resources of rice have been phenotyped for diverse agronomic traits, including yield component and abiotic/biotic stress tolerance traits at different geographical locations (multi-environment) and hot-spot regions of India for multiple years in field.

Based on phenotypic and genotypic characterization of germplasm lines, accessions contrasting for major yield component and stress tolerance traits have been selected and utilized as parents for generation of advanced biparental and back-cross mapping populations such as RILs (recombinant inbred lines) and NILs (near isogenic lines) in rice. One of the upland indica (aus) rice accession, Nagina 22, has been induced with EMS (ethyl methane sulfonate) mutagen to generate and characterize 22,292 mutant lines through an Indian National initiative involving several research institutes (Mohapatra et al. 2014). These mutant lines were phenotyped with a collaborative effort for a range of traits, which led to identify mutants for flowering, maturity, grain number and size, plant growth and architecture, yield, resistance to blast and bacterial leaf blight diseases, tolerance to drought, heat, salinity and herbicide and phosphorus use efficiency (Ashokkumar et al. 2013; Kulkarni et al. 2013; Poli et al. 2013; Mohapatra et al. 2014; Panigrahy et al. 2014; Lima et al. 2015). These mutant repositories could serve as a valuable resource for mining of novel functional alleles regulating qualitative and quantitative traits for genetic improvement in rice.

\section{Genome-Wide Scanning of Trait-Associated Functionally Relevant Molecular Tags}

Investigations by Indian researchers in the context of high-throughput SSR and SNP marker-based genotyping in advanced generation bi-parental mapping population enabled to construct high-density genetic linkage and functional transcript maps and hastened identification and mapping of genes/QTLs associated with agronomic traits in rice. For instance, about 300 QTLs governing growth and grain yield contributing traits (panicle length, days to heading/flowering, plant height, grain yield, grain weight, grain size and grain length), various quality component traits (amylose content, cooked kernel elongation ratio, aroma, grain physico-chemical and cooking quality traits, and iron and zinc concentration nutritional quality traits) and stress tolerance traits 
(sheath blight, drought and salinity resistance) have been identified and mapped on high-density SSR and SNP marker-based genetic linkage maps derived from diverse indica and aromatic rice based mapping population of rice (Marri et al. 2005; Ammar et al. 2009; Amarawathi et al. 2008; Channamallikarjuna et al. 2010; Vikram et al. 2011; Salunkhe et al. 2011; Anand et al. 2012, 2013; Anuradha et al. 2012; Guleria et al. 2012; Marathi et al. 2012; Meenakshisundaram et al. 2011; Shanmugavadivel et al. 2013). The constructed high-density genetic linkage maps have been integrated with sequence-based physical map and improved the resolution and accuracy of trait-specific genes/QTLs identification. Utilizing such map-based cloning strategy, genes harbouring major QTLs associated with diverse agronomic traits, including Pi-K $K^{h}$ (Pi54) and PPR (pentatricopeptide repeat) genes regulating blast resistance and fertility restoration have been identified in rice (Sharma et al. 2005; Reddy et al. 2008; Ngangkham et al. 2010). Recently, the integration of QTL mapping and microarray-based genome-wide transcriptome profiling of parents and bulks of homozygous RILs has been found to be a powerful approach to narrow down the number of candidate genes underlying the QTLs of interest and for isolating the possible genes regulating the traits. Using such strategy, a candidate gene belonging to glycosyl hydrolase family regulating the number of grains per panicle in a major QTL region (qGN4-1) has been mapped on chromosome 4, and two genes encoding integral transmembrane protein DUF6 and cation chloride cotransporter co-localized in the significant QTL intervals on chromosomes 1, 8, and 12 for salt ion concentrations and two known genes, badh1 and badh2 (betaine aldehyde dehydrogenase) at QTL interval governing aroma have been identified in rice (Deshmukh et al. 2010; Pandit et al. 2010; Sharma et al. 2011; Pachauri et al. 2014).

Efforts have been made by Indian scientists to mine novel allelic variants in the known cloned genes such as Pi54 and Pita regulating blast resistance, Xa21, Xa26 and $x a 5$ for bacterial blight resistance, OsDREB1F for drought tolerance, GW2 for grain size/weight and nine candidate stress responsive genes governing abiotic and biotic stress tolerance traits in rice (Singh et al. 2010c; Das et al. 2012; Parida et al. 2012; Dixit et al. 2013; Kumari et al. 2013; Devanna et al. 2014; Ramkumar et al. 2014; Bimolata et al. 2015; Singh et al. 2015c, 2015d; Thakur et al. 2015). In addition, diverse mutant populations and natural germplasm collections (core and mini-core) available for rice have been assayed through TILLING (targeting induced local lesions in genomes) and EcoTILLING to mine novel functional allelic variants in the known/candidate genes associated with various agronomic traits (Ashokkumar et al. 2013; Kulkarni et al. 2013, 2014; Poli et al. 2013; Mohapatra et al. 2014; Panigrahy et al. 2014; Lima et al. 2015). More recently, GWAS (genome-wide association study) using the genotyping information of custom designed Illumina Infinium array based on 6000 SNPs (present in many stress responsive genes distributed across 12 chromosomes with average distance of $<100 \mathrm{~kb}$ between SNP loci) assayed in 220 accessions (association panel), has been performed to identify 20 SNPs in known/candidate genes significantly associated with $\mathrm{Na}^{+} / \mathrm{K}^{+}$ratio and 44 with other salinity stress tolerance contributing traits in rice (Kumar et al. 2015).

\section{Marker-Assisted Breeding for Rice Crop Improvement}

Many successful endeavors have been made by Indian rice molecular breeders to introgress and pyramid the superior functional genes and major QTLs/alleles regulating complex yield/quality component and stress tolerance traits into diverse rice genotypes especially using marker-assisted selection (MAS) for their genetic enhancement. The genetic improvement of Basmati rice for yield, quality and resistance to bacterial leaf blight (Xa21, xa4, xa13, xa5, Xa33t, xa34t and Xa38) and blast (Pi1, Pi2, Pi5, Pi9, Pi54, Pib, Piz, Piz5, Pi-ta and Pi54/ $\left.P i-K^{h}\right)$, brown plant hopper $[B p h-3 / 17 / 18 / 20 / 21$ and $B p h 18(t)$ ], sheath blight ( $q S H B)$ and gall midge ( $G m 4$ and Gm8) diseases has been performed by pyramiding the multiple genes/QTLs through marker-assisted backcrossing (MABC)/marker-assisted foreground and background selection (Joseph et al. 2004; Sharma et al. 2005; Cheema et al. 2008; Sundaram et al. 2008, 2009; Gopalakrishnan et al. 2008; Himabindu et al. 2010; Basavaraj et al. 2010; Madhavi et al. 2011; Sama et al. 2010, 2012; Hari et al. 2011,2013; Singh et al. 2011b; Natarajkumar et al. 2012; Sujatha et al. 2010, 2013; Pandey et al. 2013; Pradhan et al. 2015). A multi-institutional National network project with an objective to introgress known cloned QTLs regulating drought (DTY1.1, DTY2.1, DTY2.2, DTY3.1, DTY3.2, DTY9.1 and DTY12.1), flood (sub-mergence) (Sub1) and salinity stress (Saltol) tolerance (http:// india.irri.org/mega-projects-in-india, Singh et al. 2015b) into high-yielding mega rice varieties (ADT46, Bahadur, MTU1075, Pooja, Rajendra, Mahsuri, Ranjit, ADT39, Pusa44, ADT45, Gayatri and Savitri) of India through MAS for their genetic enhancement for target traits is under progress. This eventually may lead to development of certain diverse genetically-tailored high-yielding and climate resilient early maturing Indian rice varieties for sustaining food security.

\section{Conclusions}

The rice genome sequence has served as a catalyst to accelerate efforts on the functional analysis of genes/ QTLs by reverse and forward genetics in India. This is 
coupled with use of genomics-assisted breeding of rice to improve traits such as yield, abiotic stress tolerance and biotic stress resistance. Diverse varieties of rice are grown in different regions of India and concerted efforts are required to introgress genes/QTLs for desirable traits into them. Some of these efforts have already led to release of improved varieties for submergence tolerance and biotic stress resistance. Indian rice researchers have highly benefited from new knowledge generated worldwide and from their own collaborative efforts in crop improvement programs. It is hoped that appropriate regulatory process will help move transgenic rice also to the field level evaluation and deregulation in due course. In the meantime, several projects related to molecular dissection of desirable agronomic traits of rice and introgression of appropriate genes/QTLs have been initiated. India is also poised to contribute to international projects in the area of functional genomics of rice and looks forward to launch of activities like riceENCODE. It is hoped that the outcome of rice genomics would go a long way to influence research in other related crops as well.

\section{Competing Interests}

The authors declare that they have no competing interest.

\section{Authors' Contributions}

PA and SKP did literature survey and compiled the information. All authors contributed to the writing and finalization of the manuscript. AKT was responsible for the overall concept. All authors read and approved the final manuscript.

\section{Acknowledgements}

Investigations in authors' labs are supported by the Department of Biotechnology and the Department of Science and Technology, Government of India.

Received: 17 July 2015 Accepted: 22 December 2015

Published online: 07 January 2016

\section{References}

Agarwal P, Arora R, Ray S, Singh AK, Singh VP, Takatsuji H, Kapoor S, Tyagi AK (2007) Genome-wide identification of $\mathrm{C} 2 \mathrm{H} 2$ zinc-finger gene family in rice and their phylogeny and expression analysis. Plant Mol Biol 65:467-485

Agarwal P, Kapoor S, Tyagi AK (2011) Transcription factors regulating the progression of monocot and dicot seed development. Bioessays 33:189-202

Agarwal P, Parida SK, Mahto A, Das S, Mathew IE, Malik N, Tyagi AK (2014) Expanding frontiers in plant transcriptomics in aid of functional genomics and molecular breeding. Biotechnol I 9:1480-1492

Aggarwal K, Shenoy V, Ramadevi J, Rajkumar R, Singh L (2002) Molecular characterization of some Indian Basmati and other elite rice genotypes using fluorescent-AFLP. Theor Appl Genet 105:680-690

Aishwarya V, Sharma PC (2007) UgMicroSatdb: database for mining microsatellites from unigenes. Nucleic Acids Res 36:D53-D56

Alexandrov N, Tai S, Wang W, Mansueto L, Palis K, Fuentes RR, Ulat VJ, Chebotarov D, Zhang G, Li Z, Mauleon R, Hamilton RS, McNally KL (2015) SNP-seek database of SNPs derived from 3000 rice genomes. Nucleic Acids Res 43:D1023-D1027

Ali N, Paul S, Gayen D, Sarkar SN, Datta K, Datta SK (2013a) Development of low phytate rice by RNAi mediated seed-specific silencing of inositol 1,3,4,5,6pentakisphosphate 2-kinase gene (IPKI). PLoS One 8:e68161

Ali N, Paul S, Gayen D, Sarkar SN, Datta SK, Datta K (2013b) RNAi mediated down regulation of myo-inositol-3-phosphate synthase to generate low phytate rice. Rice 6:12
Amarawathi Y, Singh R, Singh AK, Singh VP, Mahopatra T, Sharma TR, Singh NK (2008) Mapping of quantitative trait loci for Basmati quality traits in rice (Oryza sativa L.). Mol Breed 21:49-65

Ammar MHM, Pandit A, Singh RK, Sameena S, Chauhan MS, Singh AK, Sharma PC, Gaikwad K, Sharma TR, Mohapatra T, Singh NK (2009) Mapping of QTLS controlling $\mathrm{Na}^{+}, \mathrm{K}^{+}$and $\mathrm{Cl}^{-}$ion concentrations in salt tolerant indica rice variety CSR27. J Plant Biochem Biotechnol 18:139-150

Anand S, Tyagi AK (2010) Characterization of a pollen-preferential gene OSIAGP from rice (Oryza sativa L. subspecies indica) coding for an arabinogalactan protein homologue, and analysis of its promoter activity during pollen development and pollen tube growth. Transgenic Res 19:385-397

Anand D, Prabhu KV, Singh AK (2012) Analysis of molecular diversity and fingerprinting of commercially grown Indian rice hybrids. J Plant Biochem Biotechnol 21:173-179

Anand D, Baunthiyal M, Singh A, Gopalakrishnan S, Singh NK, Prabhu KV (2013) Validation of gene based marker-QTL association for grain dimension traits in rice. J Plant Biochem Biotechnol 22:467-473

Anuradha K, Agarwal S, Rao YV, Rao KV, Viraktamath BC, Sarla N (2012) Mapping QTLs and candidate genes for iron and zinc concentrations in unpolished rice of Madhukar x Swarna RILs. Gene 508:233-240

Archak S, Nagaraju J (2007) Computational prediction of rice (Oryza sativa) miRNA targets. Genomics Proteomics Bioinformatics 5:196-206

Arora R, Agarwal P, Ray S, Singh AK, Singh VP, Tyagi AK, Kapoor S (2007) MADSbox gene family in rice: genome-wide identification, organization and expression profiling during reproductive development and stress. BMC Genomics 8:242

Arora K, Rai AK, Gupta SK, Singh PK, Narula A, Sharma TR (2015) Phenotypic expression of blast resistance gene Pi54 is not affected by its chromosomal position. Plant Cell Rep 34:63-70

Ashokkumar K, Raveendran M, Senthil N, Vijayalaxmi D, Sowmya M, Sharma RP, Robin S (2013) Isolation and characterization of altered root growth behavior and salinity tolerant mutants in rice. Afr J Biotechnol 12:5852-5859

Babu PR, Sekhar AC, Ithal N, Markandeya G, Reddy AR (2002) Annotation and $B A C / P A C$ localization of nonredundant ESTs from drought-stressed seedlings of an indica rice. J Genet 81:25-44

Banerjee J, Maiti MK (2010) Functional role of rice germin-like protein1 in regulation of plant height and disease resistance. Biochem Biophys Res Commun 394:178-183

Banerjee J, Das N, Dey P, Maiti MK (2010) Transgenically expressed rice germinlike protein 1 in tobacco causes hyper-accumulation of $\mathrm{H}_{2} \mathrm{O}_{2}$ and reinforcement of the cell wall components. Biochem Biophys Res Commun 402:637-643

Banumathy S, Manimaran R, Sheeba A, Manivannan N, Ramya B, Kumar D, Ramasubramanian GV (2010) Genetic diversity analysis of rice germplasm lines for yield attributing traits. J Plant Breed 1:500-504

Barik S, SarkarDas S, Singh A, Gautam V, Kumar P, Majee M, Sarkar AK (2014) Phylogenetic analysis reveals conservation and diversification of micro RNA166 genes among diverse plant species. Genomics 103:114-121

Basavaraj SH, Singh VK, Singh A, Singh A, Singh A, Anand D, Yadav S, Ellur RK, Singh D, Gopalakrishnan S, Nagarajan M, Mohapatra T, Prabhu KV, Singh AK (2010) Marker-assisted improvement of bacterial blight resistance in parental lines of Pusa RH10, a superfine grain aromatic rice hybrid. Mol Breed 26:293-305

Batra G, Chauhan VS, Singh A, Sarkar NK, Grover A (2007) Complexity of rice Hsp100 gene family: lessons from rice genome sequence data. J Biosci 32:611-619

Bhattacharyya J, Chowdhury AH, Ray S, Jha JK, Das S, Gayen S, Chakraborty A, Mitra J, Maiti MK, Basu A, Sen SK (2012) Native polyubiquitin promoter of rice provides increased constitutive expression in stable transgenic rice plants. Plant Cell Rep 31:271-279

Bimolata W, Kumar A, Reddy MSK, Sundaram RM, Laha GS, Qureshi IA, Ghazi IA (2015) Nucleotide diversity analysis of three major bacterial blight resistance genes in rice. PLoS One 10:e0120186

Chakrabarty D, Trivedi PK, Misra P, Tiwari M, Shri M, Shukla D, Kumar S, Rai A, Pandey A, Nigam D, Tripathi RD, Tuli R (2009) Comparative transcriptome analysis of arsenate and arsenite stresses in rice seedlings. Chemosphere 74:688-702

Chakrabarty D, Trivedi PK, Shri M, Misra P, Asif MH, Dubey S, Kumar S, Rai A, Tiwari M, Shukla D, Pandey A, Nigam D, Tripathi RD, Tuli R (2010) Differential transcriptional expression following thidiazuron-induced callus differentiation developmental shifts in rice. Plant Biol 12:46-59

Chakraborty A, Mitra J, Bhattacharyya J, Pradhan S, Sikdar N, Das S, Chakraborty S, Kumar S, Lakhanpaul S, Sen SK (2015) Transgenic expression of an 
unedited mitochondrial orfB gene product from wild abortive (WA) cytoplasm of rice (Oryza sativa L.) generates male sterility in fertile rice lines. Planta 241:1463-1479

Channamallikarjuna V, Sonah H, Prasad M, Rao GJN, Chand S, Upreti HC, Singh NK, Sharma TR (2010) Identification of major quantitative trait loci qSBR11-1 for sheath blight resistance in rice. Mol Breed 25:155-166

Chaudhary N, Nijhawan A, Khurana JP, Khurana P (2010) Carotenoid biosynthesis genes in rice: structural analysis, genome-wide expression profiling and phylogenetic analysis. Mol Genet Genomics 283:13-33

Chauhan H, Khurana N, Agarwal P, Khurana P (2011) Heat shock factors in rice (Oryza sativa L.): genome-wide expression analysis during reproductive development and abiotic stress. Mol Genet Genomics 286:171-187

Cheema K, Grewal N, Vikal Y, Sharma R, Lore JS, Das A, Bhatia D, Mahajan R, Gupta V, Bharaj TS, Singh K (2008) A novel bacterial blight resistance gene from Oryza nivara mapped to $38 \mathrm{~kb}$ region on chromosome $4 \mathrm{~L}$ and transferred to Oryza sativa L. Genet Res 90:397-407

Chen M, Presting G, Barbazuk WB, Goicoechea JL, Blackmon B, Fang G, Kim H, Frisch D, Yu Y, Sun S, Higingbottom S, Phimphilai J, Phimphilai D, Thurmond S, Gaudette B, Li P, Liu J, Hatfield J, Main D, Farrar K, Henderson C, Barnett L, Costa R, Williams B, Walser S, Atkins M, Hall C, Budiman MA, Tomkins JP, Luo M, Bancroft I, Salse J, Regad F, Mohapatra T, Singh NK, Tyagi AK, Soderlund C, Dean RA, Wing RA (2002) An integrated physical and genetic map of the rice genome. Plant Cell 14:537-545

Choudhury DR, Singh N, Singh AK, Kumar S, Srinivasan K, Tyagi RK, Ahmad A, Singh NK, Singh R (2014) Analysis of genetic diversity and population structure of rice germplasm from North-eastern region of India and development of a core germplasm set. PLoS One 9:e113094

Dansana PK, Kothari KS, Vij S, Tyagi AK (2014) OsiSAP1 overexpression improves water-deficit stress tolerance in transgenic rice by affecting expression of endogenous stress-related genes. Plant Cell Rep 33:1425-1440

Das A, Soubam D, Singh PK, Thakur S, Singh NK, Sharma TR (2012) A novel blast resistance gene, Pi5 $4^{\text {rh }}$ cloned from wild species of rice, Oryza rhizomatis confers broad spectrum resistance to Magnaporthe oryzae. Funct Integr Genomics 12:215-228

Das B, Sengupta S, Parida SK, Roy B, Ghosh M, Prasad M, Ghose TK (2013) Genetic diversity and population structure of rice landraces from Eastern and North Eastern states of India. BMC Genet 14:71

Das-Chatterjee A, Goswami L, Maitra S, Dastidar KG, Ray S, Majumder AL (2006) Introgression of a novel salt-tolerant L-myo-inositol 1-phosphate synthase from Porteresia coarctata (Roxb.) Tateoka (PCINO1) confers salt tolerance to evolutionary diverse organisms. FEBS Lett 580:3980-3988

Deshmukh R, Singh A, Jain N, Anand S, Gacche R, Singh A, Gaikwad K, Sharma T, Mohapatra T, Singh N (2010) Identification of candidate genes for grain number in rice (Oryza sativa L.). Funct Integr Genomics 10:339-347

Deshpande GM, Ramakrishna K, Chongloi GL, Vijayraghavan U (2015) Functions for rice RFL in vegetative axillary meristem specification and outgrowth. J Exp Bot 66:2773-2784

Devanna NB, Vijayan J, Sharma TR (2014) The blast resistance gene Pi54 of cloned from Oryza officinalis interacts with Avr-Pi54 through its novel non-LRR domains. PLoS One 9:e104840

Deveshwar P, Bovill WD, Sharma R, Able JA, Kapoor S (2011) Analysis of anther transcriptomes to identify genes contributing to meiosis and male gametophyte development in rice. BMC Plant Biol 11:78

Devi SJ, Madhav MS, Kumar GR, Goel AK, Umakanth B, Jahnavi B, Viraktamath BC (2013) Identification of abiotic stress miRNA transcription factor binding motifs (TFBMs) in rice. Gene 531:15-22

Dixit N, Dokku P, Amitha Mithra SV, Parida SK, Singh AK, Singh NK, Mohapatra T (2013) Haplotype structure in grain weight gene GW2 and its association with grain characteristics in rice. Euphytica 192:55-61

Dubey S, Misra P, Dwivedi S, Chatterjee S, Bag SK, Mantri S, Asif MH, Rai A, Kumar S, Shri M, Tripathi P, Tripathi RD, Trivedi PK, Chakrabarty D, Tuli R (2010) Transcriptomic and metabolomic shifts in rice roots in response to $\mathrm{Cr}(\mathrm{VI})$ stress. BMC Genomics 11:648

Dubey S, Shri M, Misra P, Lakhwani D, Bag SK, Asif MH, Trivedi PK, Tripathi RD, Chakrabarty D (2014) Heavy metals induce oxidative stress and genome-wide modulation in transcriptome of rice root. Funct Integr Genomics 14:401-417

Ganguly M, Roychoudhury A, Sarkar SN, Sengupta DN, Datta SK, Datta K (2011) Inducibility of three salinity/abscisic acid-regulated promoters in transgenic rice with gusA reporter gene. Plant Cell Rep 30:1617-1625
Garg R, Jhanwar S, Tyagi AK, Jain M (2010) Genome-wide survey and expression analysis suggest diverse roles of glutaredoxin gene family members during development and response to various stimuli in rice. DNA Res 17:353-367

Gaur VS, Singh US, Kumar A (2011) Transcriptional profiling and in silico analysis of Dof transcription factor gene family for understanding their regulation during seed development of rice Oryza sativa L. Mol Biol Rep 38:2827-2848

Gautam N, Verma PK, Verma S, Tripathi RD, Trivedi PK, Adhikari B, Chakrabarty D (2012) Genome-wide identification of rice class I metallothionein gene: tissue expression patterns and induction in response to heavy metal stress. Funct Integr Genomics 12:635-647

Ghosh A, Pareek A, Sopory SK, Singla-Pareek SL (2014) A glutathione responsive rice glyoxalase II, OSGLYII-2, functions in salinity adaptation by maintaining better photosynthesis efficiency and anti-oxidant pool. Plant J 80:93-105

Giri J, Vij S, Dansana PK, Tyagi AK (2011) Rice A20/AN1 zinc-finger containing stress-associated proteins (SAP1/11) and a receptor-like cytoplasmic kinase (OsRLCK253) interact via A20 zinc-finger and confer abiotic stress tolerance in transgenic Arabidopsis plants. New Phytol 191:721-732

Goel A, Taj G, Pandey D, Gupta S, Kumar A (2011) Genome-wide comparative in silico analysis of calcium transporters of rice and sorghum. Genomics Proteomics Bioinformatics 9:138-150

Gopalakrishnan S, Sharma RK, Rajkumar KA, Joseph M, Singh VP, Singh AK, Bhat KV, Singh NK, Mohapatra T (2008) Integrating marker-assisted background analysis with foreground selection for identification of superior bacterial blight resistant recombinants in Basmati rice. Plant Breed 127:131-139

Gorantla M, Babu PR, Lachagari VB, Reddy AM, Wusirika R, Bennetzen JL, Reddy AR (2007) Identification of stress-responsive genes in an indica rice (Oryza sativa L.) using ESTs generated from drought-stressed seedlings. J Exp Bot 58:253-265

Gour P, Garg P, Jain R, Joseph SV, Tyagi AK, Raghuvanshi S (2014) Manually curated database of rice proteins. Nucleic Acids Res 42:D1214-D1221

Grewal RK, Gupta S, Das S (2012) Xanthomonas oryzae pv oryzae triggers immediate transcriptomic modulations in rice. BMC Genomics 13:49

Grover A, Aishwarya V, Sharma PC (2007) Biased distribution of microsatellite motifs in the rice genome. Mol Genet Genomics 277:469-480

Guleria S, Sharma V, Marathi B, Anand S, Singh S, Singh NK, Mohapatra T, Gopala S, Prabhu KV, Singh AK (2012) Molecular mapping of grain physico-chemical and cooking quality traits using recombinant inbred lines in rice (Oryza sativa L.). J Plant Biochem Biotechnol 21:1-10

Gupta SK, Rai AK, Kanwar SS, Chand D, Singh NK, Sharma TR (2012) The single functional blast resistance gene Pi54 activates a complex defence mechanism in rice. J Exp Bot 63:757-772

Gutha LR, Reddy AR (2008) Rice DREB1B promoter shows distinct stress-specific responses, and the overexpression of CDNA in tobacco confers improved abiotic and biotic stress tolerance. Plant Mol Biol 68:533-555

Hari Y, Srinivasarao K, Viraktamath BC, Hariprasad AS, Laha GS, Ahmed MI, Natarajkumar P, Ramesha MS, Neeraja CN, Balachandran SM, Rani NS, Suresh PB, Sujatha K, Pandey M, Reddy AG, Madhav MS, Sundaram RM (2011) Marker-assisted improvement of a stable restorer line, KMR-3R and its derived hybrid $\mathrm{KRH} 2$ for bacterial blight resistance and grain quality. Plant Breed 130:608-616

Hari Y, Srinivasarao K, Viraktamath BC, Hariprasad AS, Laha GS, Ahmed Ml, Natarajkumar P, Sujatha K, Prasad MS, Pandey M, Ramesha MS, Neeraja CN, Balachandran SM, Shobharani N, Kemparaju B, Madhanmohan K, Sama VSAK, Hajira SK, Baachiranjeevi CH, Pranathi K, Reddy AG, Madhav MS, Sundaram RM (2013) Marker-assisted introgression of bacterial blight and blast resistance into IR 58025B, an elite maintainer line of rice. Plant Breed 132:586-594

Himabindu K, Suneetha K, Sama V, Bentur JS (2010) A new rice gall midge resistance gene in the breeding line CR57-MR1523, mapping with flanking markers and development of NILs. Euphytica 174:179-187

Huda KM, Banu MS, Garg B, Tula S, Tuteja R, Tuteja N (2013) OsACA6, a P-type IIB $\mathrm{Ca}^{2+}$ ATPase promotes salinity and drought stress tolerance in tobacco by ROS scavenging and enhancing the expression of stress-responsive genes. Plant J 76:997-1015

International Rice Genome Sequencing Project (2005) The map-based sequence of the rice genome. Nature 436:793-800

Jain M, Kaur N, Garg R, Thakur JK, Tyagi AK, Khurana JP (2006a) Structure and expression analysis of early auxin-responsive Aux/IAA gene family in rice (Oryza sativa). Funct Integr Genomics 6:47-59

Jain M, Kaur N, Tyagi AK, Khurana JP (2006b) The auxin-responsive GH3 gene family in rice (Oryza sativa). Funct Integr Genomics 6:36-46 
Jain M, Tyagi AK, Khurana JP (2006c) Overexpression of putative topoisomerase 6 genes from rice confers stress tolerance in transgenic Arabidopsis plants. FEBS J 273:5245-5260

Jain M, Tyagi AK, Khurana JP (2006d) Genome-wide analysis, evolutionary expansion, and expression of early auxin-responsive SAUR gene family in rice (Oryza sativa). Genomics 88:360-371

Jain M, Nijhawan A, Arora R, Agarwal P, Ray S, Sharma P, Kapoor S, Tyagi AK, Khurana JP (2007) F-box proteins in rice. Genome-wide analysis, classification, temporal and spatial gene expression during panicle and seed development, and regulation by light and abiotic stress. Plant Physiol 143:1467-1483

Jain M, Khurana P, Tyagi AK, Khurana JP (2008a) Genome-wide analysis of intronless genes in rice and Arabidopsis. Funct Integr Genomics 8:69-78

Jain M, Tyagi AK, Khurana JP (2008b) Constitutive expression of a meiotic recombination protein gene homolog, OsTOP6A1, from rice confers abiotic stress tolerance in transgenic Arabidopsis plants. Plant Cell Rep 27:767-778

Jain M, Tyagi AK, Khurana JP (2008c) Genome-wide identification, classification, evolutionary expansion and expression analyses of homeobox genes in rice. FEBS J 275:2845-2861

Jain M, Moharana KC, Shankar R, Kumari R, Garg R (2014) Genomewide discovery of DNA polymorphisms in rice cultivars with contrasting drought and salinity stress response and their functional relevance. Plant Biotechnol J 12:253-264

Jha A, Shankar R (2011) Employing machine learning for reliable miRNA target identification in plants. BMC Genomics 12:636

Joseph M, Gopalakrishnan S, Sharma RK, Singh AK, Singh VP, Singh NK, Mohapatra T (2004) Combining bacterial blight resistance and Basmati quality characteristics by phenotypic and molecular marker assisted selection in rice. Mol Breed 13:377-387

Joshi PK, Gupta D, Nandal UK, Khan Y, Mukherjee SK, Sanan-Mishra N (2012) Identification of mirtrons in rice using MirtronPred: a tool for predicting plant mirtrons. Genomics 99:370-375

Kamrul Huda KM, Yadav S, Akhter Banu MS, Trivedi DK, Tuteja N (2013) Genomewide analysis of plant-type II $\mathrm{Ca}^{2+}$ ATPases gene family from rice and Arabidopsis: potential role in abiotic stresses. Plant Physiol Biochem 65:32-47

Kamrul Huda KM, Akhter Banu MS, Yadav S, Sahoo RK, Tuteja R, Tuteja N (2014) Salinity and drought tolerant OsACA6 enhances cold tolerance in transgenic tobacco by interacting with stress-inducible proteins. Plant Physiol Biochem 82:229-238

Kanneganti V, Gupta AK (2008) Overexpression of OsiSAP8, a member of stress associated protein (SAP) gene family of rice confers tolerance to salt, drought and cold stress in transgenic tobacco and rice. Plant Mol Biol 66:445-462

Kanneganti V, Gupta AK (2011) RNAi mediated silencing of a wall associated kinase, OsiWAK1 in Oryza sativa results in impaired root development and sterility due to anther indehiscence: Wall Associated Kinases from Oryza sativa. Physiol Mol Biol Plant 17:65-77

Kansal S, Devi RM, Balyan SC, Arora MK, Singh AK, Mathur S, Raghuvanshi S (2015) Unique miRNome during anthesis in drought-tolerant indica rice var. Nagina 22. Planta 241:1543-1559

Kanwar P, Sanyal SK, Tokas I, Yadav AK, Pandey A, Kapoor S, Pandey GK (2014) Comprehensive structural, interaction and expression analysis of CBL and CIPK complement during abiotic stresses and development in rice. Cell Calcium 56:81-95

Kapoor M, Arora R, Lama T, Nijhawan A, Khurana JP, Tyagi AK, Kapoor S (2008) Genome-wide identification, organization and phylogenetic analysis of Dicerlike, Argonaute and RNA-dependent RNA Polymerase gene families and their expression analysis during reproductive development and stress in rice. BMC Genomics 9:451

Katiyar A, Smita S, Lenka SK, Rajwanshi R, Chinnusamy V, Bansal KC (2012) Genome-wide classification and expression analysis of MYB transcription factor families in rice and Arabidopsis. BMC Genomics 13:544

Kaundal R, Kapoor AS, Raghava GP (2006) Machine learning techniques in disease forecasting: a case study on rice blast prediction. BMC Bioinformatics 7:485

Kaur C, Mustafiz A, Sarkar AK, Ariyadasa TU, Singla-Pareek SL, Sopory SK (2014) Expression of abiotic stress inducible ETHE1-like protein from rice is higher in roots and is regulated by calcium. Physiol Plant 152:1-16

Khurana R, Kapoor S, Tyagi AK (2013) Spatial and temporal activity of upstream regulatory regions of rice anther-specific genes in transgenic rice and Arabidopsis. Transgenic Res 22:31-46

Kulkarni KP, Vishwakarma C, Sahoo SP, Lima JM, Nath M, Dokku P, Gacche RN, Mohapatra T, Robin S, Sarla N, Seshashayee M, Singh AK, Singh K, Singh NK,
Sharma RP (2013) Phenotypic characterization and genetic analysis of dwarf and early flowering mutants of rice variety Nagina22. Oryza 50:18-25

Kulkarni KP, Vishwakarma C, Sahoo SP, Lima JM, Nath M, Dokku P, Gacche RN, Mohapatra T, Robin S, Sarla N, Seshashayee M, Singh AK, Singh K, Singh NK, Sharma RP (2014) A substitution mutation in OsCCD7 cosegregates with dwarf and increased tillering phenotype in rice. J Genet 93:389-401

Kumar K, Sinha AK (2013) Overexpression of constitutively active mitogen activated protein kinase kinase 6 enhances tolerance to salt stress in rice. Rice 6:25

Kumar K, Sinha AK (2014) Genome-wide transcriptome modulation in rice transgenic lines expressing engineered mitogen activated protein kinase kinase 6. Plant Signal Behav 9:e28502

Kumar S, Asif MH, Chakrabarty D, Tripathi RD, Trivedi PK (2011) Differential expression and alternative splicing of rice sulphate transporter family members regulate sulphur status during plant growth, development and stress conditions. Funct Integr Genomics 11:259-273

Kumar G, Kushwaha HR, Panjabi-Sabharwal V, Kumari S, Joshi R, Karan R, Mittal S, Pareek SL, Pareek A (2012) Clustered metallothionein genes are co-regulated in rice and ectopic expression of OsMTle-P confers multiple abiotic stress tolerance in tobacco via ROS scavenging. BMC Plant Biol 12:107

Kumar S, Asif MH, Chakrabarty D, Tripathi RD, Dubey RS, Trivedi PK (2013) Expression of a rice Lambda class of glutathione S-transferase, OSGSTL2, in Arabidopsis provides tolerance to heavy metal and other abiotic stresses. J Hazard Mater 248-249:228-237

Kumar SP, Pandya HA, Jasrai YT (2014) A computational model for non-conserved mature miRNAs from the rice genome. SAR QSAR Environ Res 25:205-220

Kumar V, Singh A, Amitha Mithra SV, Krishnamurthy SL, Parida SK, Jain S, Tiwari KK, Kumar P, Rao AR, Sharma SK, Khurana JP, Singh NK, Mohapatra T (2015) Genome-wide association mapping of salinity tolerance in rice (Oryza sativa). DNA Res 22:133-145

Kumari S, Sabharwal VP, Kushwaha HR, Sopory SK, Singla-Pareek SL, Pareek A (2009) Transcriptome map for seedling stage specific salinity stress response indicates a specific set of genes as candidate for saline tolerance in Oryza sativa L. Funct Integr Genomics 9:109-123

Kumari A, Das A, Devanna B, Thakur S, Singh P, Singh N, Sharma T (2013) Mining of rice blast resistance gene Pi54 shows effect of single nucleotide polymorphisms on phenotypic expression of the alleles. Eur J Plant Pathology 137:55-65

Kumari S, Joshi R, Singh K, Roy S, Tripathi AK, Singh P, Singla-Pareek SL, Pareek A (2015) Expression of a cyclophilin OsCyp2-P isolated from a salt-tolerant landrace of rice in tobacco alleviates stress via ion homeostasis and limiting ROS accumulation. Funct Integr Genomics. 15:395-412

Kushwaha HR, Singh AK, Sopory SK, Singla-Pareek SL, Pareek A (2009) Genome wide expression analysis of CBS domain containing proteins in Arabidopsis thaliana (L.) Heynh and Oryza sativa L. reveals their developmental and stress regulation. BMC Genomics 10:200

Lakra N, Nutan KK, Das P, Anwar K, Singla-Pareek SL, Pareek A (2015) A nuclearlocalized histone-gene binding protein from rice (OsHBP1b) functions in salinity and drought stress tolerance by maintaining chlorophyll content and improving the antioxidant machinery. J Plant Physiol 176:36-46

Lenka SK, Katiyar A, Chinnusamy V, Bansal KC (2011) Comparative analysis of drought-responsive transcriptome in indica rice genotypes with contrasting drought tolerance. Plant Biotechnol J 9:315-327

Li JY, Wang J, Zeigler RS (2014) The 3,000 rice genomes project: new opportunities and challenges for future rice research. Gigascience 3:8

Lima JM, Nath M, Dokku P, Raman KV, Kulkarni KP, Vishwakarma C, Sahoo SP, Mohapatra UB, Amitha Mithra SV, Chinnusamy V, Robin S, Sarla N, Seshashayee M, Singh K, Singh AK, Singh NK, Sharma RP, Mohapatra T (2015) Physiological, anatomical and transcriptional alterations in a rice mutant leading to enhanced water stress tolerance. AoB Plants. 7:plv023

Macovei A, Tuteja N (2012) microRNAs targeting DEAD-box helicases are involved in salinity stress response in rice (Oryza sativa L.). BMC Plant Biol 12:183

Madhavi KR, Prasad MS, Laha GS, Mohan KM, Madhav MS, Viraktamath BC (2011) Combining blast and bacterial blight resistance in rice cultivar, improved Samba Mahsuri. Indian J Plant Protect 39:124-129

Majee M, Maitra S, Dastidar KG, Pattnaik S, Chatterjee A, Hait NC, Das KP, Majumder AL (2004) A novel salt-tolerant L-myo-inositol-1-phosphate synthase from Porteresia coarctata (Roxb.) Tateoka, a halophytic wild rice: molecular cloning, bacterial overexpression, characterization, and functional introgression into tobacco-conferring salt tolerance phenotype. J Biol Chem 279:28539-28552 
Mallikarjuna G, Mallikarjuna K, Reddy MK, Kaul T (2011) Expression of OsDREB2A transcription factor confers enhanced dehydration and salt stress tolerance in rice (Oryza sativa L.). Biotechnol Lett 33:1689-1697

Manimaran P, Mangrauthia SK, Sundaram RM, Balachandran SM (2015) Constitutive expression and silencing of a novel seed specific calcium dependent protein kinase gene in rice reveals its role in grain filling. J Plant Physiol 174:41-48

Marathi B, Guleria S, Mohapatra T, Parsad R, Mariappan N, Kurungara VK, Atwal SS, Prabhu KV, Singh NK, Singh AK (2012) QTL analysis of novel genomic regions associated with yield and yield related traits in new plant type based recombinant inbred lines of rice (Oryza sativa L.). BMC Plant Biol 12:137-137

Marla SS, Singh VK (2012) LOX genes in blast fungus (Magnaporthe grisea) resistance in rice. Funct Integr Genomics 12:265-275

Marri PR, Sarla N, Reddy LV, Siddiq EA (2005) Identification and mapping of yield and yield related QTLs from an Indian accession of Oryza rufipogon. BMC Genet 6:33

Mathur S, Vyas S, Kapoor S, Tyagi AK (2011) The Mediator complex in plants: structure, phylogeny, and expression profiling of representative genes in a dicot (Arabidopsis) and a monocot (rice) during reproduction and abiotic stress. Plant Physiol 157:1609-1627

McCouch SR, Teytelman L, Xu Y, Lobos KB, Clare K, Walton M, Fu B, Maghirang R, Li Z, Xing Y, Zhang Q, Kono I, Yano M, Fjellstrom R, DeClerck G, Schneider D, Cartinhour S, Ware D, Stein L (2002) Development of 2240 new SSR markers for rice (Oryza sativa L.). DNA Res 9:199-207

Meenakshisundaram P, Patel SB, Sudha M, Geethanjali S, Vinod KK, Selvaraju K, Govindaraj P, Arumugachamy S, Shanmugasundaram P, Maheswaran M (2011) Microsatellite marker based linkage map construction and mapping of granule bound starch synthase (GBSS) in rice using recombinant inbred lines of the cross Basmati 370/ASD16. Crop Improv 38:155-162

Meti N, Samal KC, Bastia DN, Rout GR (2013) Genetic diversity analysis in aromatic rice genotypes using microsatellite based simple sequence repeats (SSR) marker. Afr J Biotechnol 12:4238-4250

Mittal D, Chakrabarti S, Sarkar A, Singh A, Grover A (2009) Heat shock factor gene family in rice: genomic organization and transcript expression profiling in response to high temperature, low temperature and oxidative stresses. Plant Physiol Biochem 47:785-795

Mittal D, Madhyastha DA, Grover A (2012a) Gene expression analysis in response to low and high temperature and oxidative stresses in rice: combination of stresses evokes different transcriptional changes as against stresses applied individually. Plant Sci 197:102-113

Mittal D, Madhyastha DA, Grover A (2012b) Genome-wide transcriptional profiles during temperature and oxidative stress reveal coordinated expression patterns and overlapping regulons in rice. PLoS One 7:e40899

Mittal D, Mukherjee SK, Vasudevan M, Mishra NS (2013) Identification of tissuepreferential expression patterns of rice miRNAs. J Cell Biochem 114:2071-2081

Mohapatra T, Robin S, Sarla N, Sheshashayee M, Singh AK, Singh K, Singh NK, Amitha Mithra SV, Sharma RP (2014) EMS induced mutants of upland rice variety Nagina22: generation and characterization. Proc Indian Natl Sci Acad 80:163-172

Molla KA, Karmakar S, Chanda PK, Ghosh S, Sarkar SN, Datta SK, Datta K (2013) Rice oxalate oxidase gene driven by green tissue-specific promoter increases tolerance to sheath blight pathogen (Rhizoctonia solani) in transgenic rice. Mol Plant Pathol 14:910-922

Mondal TK, Ganie SA (2014) Identification and characterization of salt responsive miRNA-SSR markers in rice (Oryza sativa). Gene 535:204-209

Mukhopadhyay P, Tyagi AK (2015) OsTCP19 influences developmental and abiotic stress signaling by modulating ABI4-mediated pathways. Sci Rep 29:9998

Mukhopadhyay A, Vij S, Tyagi AK (2004) Overexpression of a zinc-finger protein gene from rice confers tolerance to cold, dehydration, and salt stress in transgenic tobacco. Proc Natl Acad Sci U S A 101:6309-6314

Mustafiz A, Singh AK, Pareek A, Sopory SK, Singla-Pareek SL (2011) Genome-wide analysis of rice and Arabidopsis identifies two glyoxalase genes that are highly expressed in abiotic stresses. Funct Integr Genomics 11:293-305

Mutum RD, Balyan SC, Kansal S, Agarwal P, Kumar S, Kumar M, Raghuvanshi S (2013) Evolution of variety-specific regulatory schema for expression of osamiR408 in indica rice varieties under drought stress. FEBS J 280:1717-1730

Nagaraju J, Kathirvel M, Kumar RR, Siddiq EA, Hasnain SE (2002) Genetic analysis of traditional and evolved Basmati and non-Basmati rice varieties by using fluorescence-based ISSR-PCR and SSR markers. Proc Natl Acad Sci U S A 99:5836-5841
Naik PK, Mittal VK, Gupta S (2008) RetroPred: A tool for prediction, classification and extraction of non-LTR retrotransposons (LINEs \& SINEs) from the genome by integrating PALS, PILER, MEME and ANN. Bioinformation 2:263-270

Naika M, Shameer K, Mathew OK, Gowda R, Sowdhamini R (2013) STIFDB2: an updated version of plant stress-responsive transcription factor database with additional stress signals, stress-responsive transcription factor binding sites and stress-responsive genes in Arabidopsis and rice. Plant Cell Physiol 54:e8

Natarajkumar P, Sujatha K, Laha GS, Rao KS, Mishra B, Viraktamath BC, Hari Y, Reddy CS, Balachandran SM, Ram T, Madhav MS, Rani NS, Neeraja CN, Reddy GA, Shaik H, Sundaram RM (2012) Identification and fine-mapping of Xa33, a novel gene for resistance to Xanthomonas oryzae pv. oryzae. Phytopathology 102:222-228

Nayar S, Sharma R, Tyagi AK, Kapoor S (2013) Functional delineation of rice MADS29 reveals its role in embryo and endosperm development by affecting hormone homeostasis. J Exp Bot 64:4239-4253

Nayar S, Kapoor M, Kapoor S (2014) Post-translational regulation of rice MADS29 function: homodimerization or binary interactions with other seed-expressed MADS proteins modulate its translocation into the nucleus. J Exp Bot 65: 5339-53350

Ngangkham U, Parida SK, De S, Kumar KAR, Singh AK, Singh NK, Mohapatra T (2010) Genic markers for wild abortive (WA) cytoplasm based male sterility and its fertility restoration in rice. Mol Breed 26:275-292

Nigam D, Kumar S, Mishra DC, Rai A, Smita S, Saha A (2015) Synergistic regulatory networks mediated by microRNAs and transcription factors under drought, heat and salt stresses in Oryza sativa spp. Gene 555:127-139

Nijhawan A, Jain M, Tyagi AK, Khurana JP (2008) Genomic survey and gene expression analysis of the basic leucine zipper transcription factor family in rice. Plant Physiol 146:333-350

Nischal L, Mohsin M, Khan I, Kardam H, Wadhwa A, Abrol YP, lqbal M, Ahmad A (2012) Identification and comparative analysis of microRNAs associated with low-N tolerance in rice genotypes. PLoS One 7:e50261

Pachauri V, Mishra V, Mishra P, Singh AK, Singh S, Singh R, Singh NK (2014) Identification of candidate genes for rice grain aroma by combining QTL mapping and transcriptome profiling approaches. Cereal Res Comm 42:376-388

Pandey MK, Rani NS, Sundaram RM, Laha GS, Madhav MS, Rao KS, Sudharshan I, Hari Y, Varaprasad GS, Rao LVS, Suneetha K, Sivaranjani AKP, Viraktamath BC (2013) Improvement of two traditional Basmati rice varieties for bacterial blight resistance and plant stature through morphological and markerassisted selection. Mol Breed 31:239-246

Pandey C, Raghuram B, Sinha AK, Gupta M (2015) miRNA plays a role in the antagonistic effect of selenium on arsenic stress in rice seedlings. Metallomics 7:857-866

Pandit A, Rai V, Bal S, Sinha S, Kumar V, Chauhan M, Gautam RK, Singh R, Sharma PC, Singh AK, Gaikwad K, Sharma TR, Mohapatra T, Singh NK (2010) Combining QTL mapping and transcriptome profiling of bulked RILs for identification of functional polymorphism for salt tolerance genes in rice (Oryza sativa L.). Mol Genet Genomics 284:121-136

Panigrahy M, Rao DN, Yugandhar P, Raju NS, Krishnamurthya P, Voletia SR, Reddy GA, Mohapatra T, Robin S, Singh AK, Singh K, Sheshshayeef M, Sharma RP, Sarla N (2014) Hydroponic experiment for identification of tolerance traits developed by rice Nagina22 mutants to low-phosphorus in field condition. Arch Agron Soil Sci 60:565-576

Pareek A, Singh A, Kumar M, Kushwaha HR, Lynn AM, Singla-Pareek SL (2006) Whole-genome analysis of Oryza sativa reveals similar architecture of twocomponent signaling machinery with Arabidopsis. Plant Physiol 142:380-397

Parida SK, Kumar KA, Dalal V, Singh NK, Mohaptra T (2006) Unigene derived microsatellite markers for the cereal genomes. Theor Appl Genet 112:808-817

Parida SK, Dalal V, Singh AK, Singh NK, Mohaptra T (2009) Genic non-coding microsatellites in the rice genome: characterization, marker design and use in assessing genetic and evolutionary relationships among domesticated groups. BMC Genomics 10:140

Parida SK, Mukerji M, Singh AK, Singh NK, Mohapatra T (2012) SNPs in stressresponsive rice genes: validation, genotyping, functional relevance and population structure. BMC Genomics 13:426

Patel S, Ravikiran R, Chakraborty S, Macwana S, Sasidharan N, Trivedi R, Aher B (2014) Genetic diversity analysis of colored and white rice genotypes using microsatellite (SSR) and Insertion-Deletion (INDEL) markers. Emir J Food Agric 26:497-507

Patra B, Ray S, Richter A, Majumder AL (2010) Enhanced salt tolerance of transgenic tobacco plants by co-expression of PCINO1 and McIMT1 is 
accompanied by increased level of myo-inositol and methylated inositol. Protoplasma 245:143-152

Paul P, Chakraborty S (2013) Computational prediction of submergence responsive microRNA and their binding position within the genome of Oryza sativa. Bioinformation 9:858-863

Poli Y, Basava RK, Panigrahy M, Vinukonda VP, Dokula NR, Voleti SR, Desiraju S, Neelamraju S (2013) Characterization of a Nagina22 rice mutant for heat tolerance and mapping of yield traits. Rice 6:36

Pradhan SK, Nayak DK, Mohanty S, Behera L, Barik SR, Pandit E, Lenka S, Anandan A (2015) Pyramiding of three bacterial blight resistance genes for broadspectrum resistance in deepwater rice variety, Jalmagna. Rice 8:19

Prasad K, Sriram P, Kumar CS, Kushalappa K, Vijayraghavan U (2001) Ectopic expression of rice OsMADS1 reveals a role in specifying the lemma and palea, grass floral organs analogous to sepals. Dev Genes Evol 211:281-290

Prasad K, Kushalappa K, Vijayraghavan U (2003) Mechanism underlying regulated expression of RFL, a conserved transcription factor, in the developing rice inflorescence. Mech Dev 120:491-502

Prasad BD, Creissen G, Lamb C, Chattoo BB (2009) Overexpression of rice (Oryza sativa L.) OsCDR1 leads to constitutive activation of defense responses in rice and Arabidopsis. Mol Plant Microbe Interact 22:1635-1644

Prasad SG, Sujatha M, Rao SLV, Chaitanya U (2013) Screening of indica rice (Oryza sativa L.) genotypes against low temperature stress using diversity analysis. Helix 2:280-283

Prashanth SR, Parani M, Mohanty BP, Talame V, Tuberosa R, Parida A (2002) Genetic diversity in cultivars and landraces of Oryza sativa subsp. indica as revealed by AFLP markers. Genome 45:451-459

Priya P, Jain M (2013) RiceSRTFDB: a database of rice transcription factors containing comprehensive expression, cis-regulatory element and mutant information to facilitate gene function analysis. Database (Oxford). 2013: bat027. doi:10.1093/database/bat027

Raghuram B, Sheikh AH, Sinha AK (2014) Regulation of MAP kinase signaling cascade by microRNAs in Oryza sativa. Plant Signal Behav 9:e972130

Ramkumar G, Madhav MS, Devi SJSR, Manimaran P, Mohan KM, Prasad MS, Balachandran SM, Neeraja CN, Sundaram RM, Viraktamath BC (2014) Nucleotide diversity of Pita, a major blast resistance gene and identification of its minimal promoter. Gene 546:250-256

Rao NN, Prasad K, Kumar PR, Vijayraghavan U (2008) Distinct regulatory role for $R F L$, the rice $L F Y$ homolog, in determining flowering time and plant architecture. Proc Natl Acad Sci U S A 105:3646-3651

Rao KP, Richa T, Kumar K, Raghuram B, Sinha AK (2010) In silico analysis reveals 75 members of mitogen-activated protein kinase kinase kinase gene family in rice. DNA Res 17:139-153

Rathinasabapathi P, Purushothaman N, Ramprasad VL, Parani M (2015) Whole genome sequencing and analysis of Swarna, a widely cultivated indica rice variety with low glycemic index. Sci Rep 5:11303

Ray S, Agarwal P, Arora R, Kapoor S, Tyagi AK (2007) Expression analysis of calcium-dependent protein kinase gene family during reproductive development and abiotic stress conditions in rice (Oryza sativa L. ssp. indica). Mol Genet Genomics 278:493-505

Ray S, Dansana PK, Giri J, Deveshwar P, Arora R, Agarwal P, Khurana JP, Kapoor S, Tyagi AK (2011) Modulation of transcription factor and metabolic pathway genes in response to water-deficit stress in rice. Funct Integr Genomics 11:157-178

Ray S, Kapoor S, Tyagi AK (2012) Analysis of transcriptional and upstream regulatory sequence activity of two environmental stress-inducible genes, NBS-Str1 and BLEC-Str8, of rice. Transgenic Res 21:351-366

Reddy AR, Ramakrishna W, Sekhar AC, Ithal N, Babu PR, Bonaldo MF, Soares MB, Bennetzen $J L$ (2002) Novel genes are enriched in normalized CDNA libraries from drought-stressed seedlings of rice (Oryza sativa L. subsp. indica cV. Nagina 22). Genome 45:204-211

Reddy AM, Reddy VS, Scheffler BE, Wienand U, Reddy AR (2007) Novel transgenic rice overexpressing anthocyanidin synthase accumulates a mixture of flavonoids leading to an increased antioxidant potential. Metab Eng 9:95-111

Reddy BPN, Deshmukh RK, Gupta B, Deshmukh NK, Bhaganagare G, Shivraj SM, Singh T, Kotashane AS (2008) Identification of candidate genes for bacterial leaf blight resistance in rice by integration of genetic QTL map with the physical map. Asian J Bio Sci 3:24-29

Rice Annotation Project (2007) Curated genome annotation of Oryza sativa ssp. japonica and comparative genome analysis with Arabidopsis thaliana. Genome Res 17:175-183
Rice Annotation Project (2008) The Rice Annotation Project Database (RAP-DB): 2008 update. Nucleic Acids Res 36:D1028-D1033

Rice Chromosomes 11 and 12 Sequencing Consortia (2005) The sequence of rice chromosomes 11 and 12, rich in disease resistance genes and recent gene duplications. BMC Biol 3:20

RoyChoudhury A, Roy C, Sengupta DN (2007) Transgenic tobacco plants overexpressing the heterologous lea gene Rab16A from rice during high salt and water deficit display enhanced tolerance to salinity stress. Plant Cell Rep 26:1839-1859

Saha P, Chakraborti D, Sarkar A, Dutta I, Basu D, Das S (2007) Characterization of vascular-specific RSs 1 and ro/C promoters for their utilization in engineering plants to develop resistance against hemipteran insect pests. Planta 226:429-442

Saha J, Sengupta A, Gupta K, Gupta B (2015) Molecular phylogenetic study and expression analysis of ATP-binding cassette transporter gene family in Oryza sativa in response to salt stress. Comput Biol Chem 54:18-32

Sahoo RK, Ansari MW, Pradhan M, Dangar TK, Mohanty S, Tuteja N (2014a) Phenotypic and molecular characterization of native Azospirillum strains from rice fields to improve crop productivity. Protoplasma 251:943-953

Sahoo RK, Ansari MW, Tuteja R, Tuteja N (2014b) OsSUV3 transgenic rice maintains higher endogenous levels of plant hormones that mitigates adverse effects of salinity and sustains crop productivity. Rice 7:17

Sajib AM, Hossain MM, Mosnaz ATMJ, Hossain H, Islam MM, Ali MS, Prodhan SH (2012) SSR marker-based molecular characterization and genetic diversity analysis of aromatic landraces of rice (Oryza sativa L.). J BioSci Biotechnol 1:107-116

Salunkhe AS, Poornima R, Prince KS, Kanagaraj P, Sheeba JA, Amudha K, Suji KK, Senthil A, Babu RC (2011) Fine mapping QTL for drought resistance traits in rice (Oryza sativa L.) using bulk segregant analysis. Mol Biotechnol 49:90-95

Sama VSAK, Himabindu K, Sundaram RM, Viraktamath BC, Bentur JS (2010) Mapping of a rice gall midge resistance gene, gm3, in RP 2068-18-3-5 and in silico identification of candidate gene(s). Rice Genet Newsl 25:76

Sama VSAK, Himabindu K, Naik SB, Sundaram RM, Viraktamath BC, Bentur JS (2012) Mapping and MAS breeding of an allelic gene to the Gm8 for resistance to Asian rice gall midge. Euphytica 187:393-400

Sanan-Mishra N, Kumar V, Sopory SK, Mukherjee SK (2009) Cloning and validation of novel miRNA from Basmati rice indicates cross talk between abiotic and biotic stresses. Mol Genet Genomics 282:463-474

Sarkar NK, Kim YK, Grover A (2009) Rice sHsp genes: genomic organization and expression profiling under stress and development. BMC Genomics 10:393

Sarkar NK, Kundnani P, Grover A (2013) Functional analysis of Hsp70 superfamily proteins of rice (Oryza sativa). Cell Stress Chaperones 18:427-437

Sarkar NK, Kim YK, Grover A (2014) Coexpression network analysis associated with call of rice seedlings for encountering heat stress. Plant Mol Biol 84:125-143

Shankar A, Singh A, Kanwar P, Srivastava AK, Pandey A, Suprasanna P, Kapoor S, Pandey GK (2013) Gene expression analysis of rice seedling under potassium deprivation reveals major changes in metabolism and signaling components. PLOS One 8:e70321

Shankar A, Srivastava AK, Yadav AK, Sharma M, Pandey A, Raut W, Das MK, Suprasanna P, Pandey GK (2014) Whole genome transcriptome analysis of rice seedling reveals alterations in $\mathrm{Ca}^{2+}$ ion signaling and homeostasis in response to $\mathrm{Ca}^{2+}$ deficiency. Cell Calcium 55:155-165

Shanmugavadivel PS, Mithra SVA, Dokku P, Kumar KAR, Rao GJN, Singh VP, Singh AK, Singh NK, Mohapatra T (2013) Mapping quantitative trait loci (QTL) for grain size in rice using a RIL population from Basmati x indica cross showing high segregation distortion. Euphytica 194:401-416

Sharma TR, Madhav MS, Singh BK, Shanker P, Jana TK, Dalal V, Pandit A, Singh A, Gaikwad K, Upreti HC, Singh NK (2005) High-resolution mapping, cloning and molecular characterization of the gene of rice, which confers resistance to rice blast. Mol Genet Genomics 274:569-578

Sharma A, Deshmukh RK, Jain N, Singh NK (2011) Combining QTL mapping and transcriptome profiling for an insight into genes for grain number in rice (Oryza sativa L.). Indian J Genet 71:115-119

Sharma R, Agarwal P, Ray S, Deveshwar P, Sharma P, Sharma N, Nijhawan A, Jain $M$, Singh AK, Singh VP, Khurana JP, Tyagi AK, Kapoor S (2012) Expression dynamics of metabolic and regulatory components across stages of panicle and seed development in indica rice. Funct Integr Genomics 12:229-248

Sharma R, Priya P, Jain M (2013) Modified expression of an auxin-responsive rice CC-type glutaredoxin gene affects multiple abiotic stress responses. Planta 238:871-884 
Sharma M, Singh A, Shankar A, Pandey A, Baranwal V, Kapoor S, Tyagi AK, Pandey GK (2014a) Comprehensive expression analysis of rice Armadillo gene family during abiotic stress and development. DNA Res 21:267-283

Sharma R, Sahoo A, Devendran R, Jain M (2014b) Over-expression of a rice tau class glutathione s-transferase gene improves tolerance to salinity and oxidative stresses in Arabidopsis. PLoS One 9:e92900

Sharma D, Tiwari M, Lakhwani D, Tripathi RD, Trivedi PK (2015) Differential expression of microRNAs by arsenate and arsenite stress in natural accessions of rice. Metallomics 7:174-187

Singh RK, Sharma RK, Singh AK, Singh VP, Singh NK, Tiwari SP, Mohapatra T (2004) Suitability of mapped sequence tagged microatellite site markers for establishing distinctness, uniformaity and stability in aromatic rice. Euphytica 135:135-143

Singh A, Sahi C, Grover A (2009) Chymotrypsin protease inhibitor gene family in rice: Genomic organization and evidence for the presence of a bidirectional promoter shared between two chymotrypsin protease inhibitor genes. Gene 428:9-19

Singh A, Giri J, Kapoor S, Tyagi AK, Pandey GK (2010a) Protein phosphatase complement in rice: genome-wide identification and transcriptional analysis under abiotic stress conditions and reproductive development. BMC Genomics 11:435

Singh A, Singh PK, Singh R, Pandit A, Mahato AK, Gupta DK, Tyagi K, Singh AK, Singh NK, Sharma TR (2010b) SNP haplotypes of the BADH1 gene and their association with aroma in rice (Oryza sativa L.). Mol Breed 26:325-338

Singh H, Deshmukh RK, Singh A, Singh AK, Gaikwad K, Sharma TR, Mohapatra T, Singh NK (2010c) Highly variable SSR markers suitable for rice genotyping using agarose gels. Mol Breed 25:359-364

Singh AK, Gopalakrishnan S, Singh VP, Prabhu KV, Mohapatra T, Singh NK, Sharma TR, Nagarajan M, Vinod KK, Singh D, Singh UD, Subhash C, Atwal SS, Rakesh S, Singh VK, Ranjith KE, Singh A, Deepti A, Apurva K, Sheel Y, Nitika G, Singh A, Shikari AB, Singh A, Marathi B (2011a) Marker assisted selection: a paradigm shift in Basmati breeding. Indian J Genet 71:1-9

Singh SK, Singh CM, Lal GM (2011b) Assessment of genetic variability for yield and its component characters in rice (Oryza sativa L.). Res Plant Biol 1:73-76

Singh A, Baranwal V, Shankar A, Kanwar P, Ranjan R, Yadav S, Pandey A, Kapoor S, Pandey GK (2012a) Rice phospholipase A superfamily: organization, phylogenetic and expression analysis during abiotic stresses and development. PLoS One 7:e30947

Singh A, Mittal D, Lavania D, Agarwal M, Mishra RC, Grover A (2012b) OsHsfA2C and $\mathrm{OsHsfB} 4 b$ are involved in the transcriptional regulation of cytoplasmic OsClpB (Hsp100) gene in rice (Oryza sativa L.). Cell Stress Chaperones 17:243-254

Singh AK, Kumar R, Pareek A, Sopory SK, Singla-Pareek SL (2012c) Overexpression of rice CBS domain containing protein improves salinity, oxidative, and heavy metal tolerance in transgenic tobacco. Mol Biotechnol 52:205-216

Singh A, Kanwar P, Pandey A, Tyagi AK, Sopory SK, Kapoor S, Pandey GK (2013a) Comprehensive genomic analysis and expression profiling of phospholipase C gene family during abiotic stresses and development in rice. PLoS One 8:e62494

Singh A, Singh B, Panda K, Rai VP, Singh AK, Singh SP, Chouhan SK, Vandna R, Kumar P, Singh NK (2013b) Wild rices of Eastern Indo-gangetic plains of India constitute two sub-populations harbouring rich genetic diversity. J Plant Mol Biol Omics 62:121-127

Singh N, Choudhury DR, Singh AK, Kumar S, Srinivasan K, Tyagi RK, Singh NK, Singh $R$ (2013c) Comparison of SSR and SNP markers in estimation of genetic diversity and population structure of Indian rice varieties. PLoS One 8:e84136

Singh S, Giri MK, Singh PK, Siddiqui A, Nandi AK (2013d) Down-regulation of OsSAG12-1 results in enhanced senescence and pathogen-induced cell death in transgenic rice plants. J Biosci 38:583-592

Singh A, Jha SK, Bagri J, Pandey GK (2015a) ABA inducible rice protein phosphatase $2 C$ confers $A B A$ insensitivity and abiotic stress tolerance in Arabidopsis. PLoS One 10:e0125168

Singh BP, Jayaswal PK, Singh B, Singh PK, Kumar V, Mishra S, Singh N, Panda K, Singh NK (2015b) Natural allelic diversity in OsDREB1F gene in the Indian wild rice germplasm led to ascertain its association with drought tolerance. Plant Cell Rep 34:993-1004

Singh N, Jayaswal PK, Panda K, Mandal P, Kumar V, Singh B, Mishra S, Singh Y, Singh R, Rai V, Gupta A, Sharma TR, Singh NK (2015c) Single-copy gene based 50 K SNP chip for genetic studies and molecular breeding in rice. Sci Rep 5:11600

Singh S, Chand S, Singh NK, Sharma TR (2015d) Genome-wide distribution, organisation and functional characterization of disease resistance and defence response genes across rice species. PLoS One 10:e0125964
Singla B, Khurana JP, Khurana P (2009) Structural characterization and expression analysis of the SERK/SERL gene family in rice (Oryza sativa). Int J Plant Genomics 2009:539402

Singla-Pareek SL, Yadav SK, Pareek A, Reddy MK, Sopory SK (2008) Enhancing salt tolerance in a crop plant by overexpression of glyoxalase II. Transgenic Res 17:171-180

Smita S, Lenka SK, Katiyar A, Jaiswal P, Preece J, Bansal KC (2011) QlicRice: a web interface for abiotic stress responsive QTL and loci interaction channels in rice. Database (Oxford). 2011:bar037. doi:10.1093/database/bar037

Smita S, Katiyar A, Pandey DM, Chinnusamy V, Archak S, Bansal KC (2013) Identification of conserved drought stress responsive gene-network across tissues and developmental stages in rice. Bioinformation 9:72-78

Subbaiyan GK, Waters DL, Katiyar SK, Sadananda AR, Vaddadi S, Henry RJ (2012) Genome-wide DNA polymorphisms in elite indica rice inbreds discovered by whole-genome sequencing. Plant Biotechnol J 10:623-634

Sujatha K, Natarajkumar P, Laha GS, Viraktamath BC, Reddy CS, Mishra B, Balachandran SM, Ram T, Srinivasarao K, Hari Y, Kirti PB, Sundaram RM (2010) Molecular mapping of a recessive bacterial blight resistance gene derived from Oryza. Rice Genet Newsl 25:1-2

Sujatha K, Prasad MS, Pandey M, Ramesha MS, Neeraja CN, Balachandran SM, Shobharani N, Kemparaju B, Madhanmohan K, Sama VSAK, Hajira SK, Baachiranjeevi CH, Pranathi K, Reddy GA, Madhav MS, Sundaram RM (2013) Marker-assisted introgression of bacterial blight and blast resistance into IR 58025B, an elite maintainer line of rice. Plant Breed 132:586-594

Sundaram RM, Vishnupriya MR, Biradar SK, Laha GS, Reddy GA, Shoba Rani N, Sarma NP, Sonti RV (2008) Marker assisted introgression of bacterial blight resistance in Samba Mahsuri, an elite indica rice variety. Euphytica 160:411-422

Sundaram RM, Vishnupriya MR, Laha GS, Rani NS, Rao PS, Balachandran SM, Reddy GA, Sarma NP, Sonti RV (2009) Introduction of bacterial blight resistance into Triguna, a high yielding, mid-early duration rice variety. Biotechnol J 4:400-407

Swapna L, Khurana R, Kumar SV, Tyagi AK, Rao KV (2011) Pollen-specific expression of Oryza sativa indica pollen allergen gene (OsIPA) promoter in rice and Arabidopsis transgenic systems. Mol Biotechnol 48:49-59

Thakur JK, Agarwal P, Parida S, Bajaj D, Pasrija R (2013) Sequence and expression analyses of KIX domain proteins suggest their importance in seed development and determination of seed size in rice, and genome stability in Arabidopsis. Mol Genet Genomics 288:329-346

Thakur S, Singh PK, Das A, Rathour R, Variar M, Prashanthi SK, Singh AK, Singh UD, Chand D, Singh NK, Sharma TR (2015) Extensive sequence variation in rice blast resistance gene Pi54 makes it broad spectrum in nature. Front Plant Sci 6:345

Tiwari M, Sharma D, Singh M, Tripathi RD, Trivedi PK (2014) Expression of OSMATE1 and OSMATE2 alters development, stress responses and pathogen susceptibility in Arabidopsis. Sci Rep 4:3964

Tiwari KK, Singh A, Pattnaik S, Sandhu M, Kaur S, Jain S, Tiwari S, Mehrotra S, Anumalla M, Samal R, Bhardwaj J, Dubey N, Sahu V, Kharshing GA, Zeliang PK, Sreenivasan K, Kumar P, Parida SK, Mithra SVA, Rai V, Tyagi W, Agarwal PK, Rao AR, Pattanayak A, Chandel G, Singh AK, Bisht IS, Bhat KV, Rao GJN, Khurana JP, Singh NK, Mohapatra T (2015a) Identification of a diverse minicore panel of Indian rice germplasm based on genotyping using microsatellite markers. Plant Breed 134:164-171

Tiwari LD, Mittal D, Chandra Mishra R, Grover A (2015b) Constitutive overexpression of rice chymotrypsin protease inhibitor gene OCPI2 results in enhanced growth, salinity and osmotic stress tolerance of the transgenic Arabidopsis plants. Plant Physiol Biochem 92:48-55

Trivedi DK, Yadav S, Vaid N, Tuteja N (2012) Genome wide analysis of Cyclophilin gene family from rice and Arabidopsis and its comparison with yeast. Plant Signal Behav 7:1653-1666

Tuteja N, Sahoo RK, Garg B, Tuteja R (2013) OsSUV3 dual helicase functions in salinity stress tolerance by maintaining photosynthesis and antioxidant machinery in rice (Oryza sativa L. CV. IR64). Plant J 76:115-127

Tyagi H, Jha S, Sharma M, Giri J, Tyagi AK (2014) Rice SAPs are responsive to multiple biotic stresses and overexpression of OsSAP1, an A20/AN1 zincfinger protein, enhances the basal resistance against pathogen infection in tobacco. Plant Sci 225:68-76

Umate P (2010) Genome-wide analysis of thioredoxin fold superfamily peroxiredoxins in Arabidopsis and rice. Plant Signal Behav 5:1543-1546

Umate P (2011) Genome-wide analysis of lipoxygenase gene family in Arabidopsis and rice. Plant Signal Behav 6:335-338 
Umate P, Tuteja N (2010) microRNA access to the target helicases from rice. Plant Signal Behav 5:1171-1175

Umate P, Tuteja R, Tuteja N (2010) Genome-wide analysis of helicase gene family from rice and Arabidopsis: a comparison with yeast and human. Plant Mol Biol 73:449-465

Vaid N, Pandey PK, Tuteja N (2012) Genome-wide analysis of lectin receptor-like kinase family from Arabidopsis and rice. Plant Mol Biol 80:365-388

Vhora Z, Trivedi R, Chakraborty S, Ravikiran R, Sasidharan N (2013) Molecular studies of aromatic and non-aromatic rice (Oryza sativa L.) genotypes for quality traits using microsatellite markers. Bioscan 8:359-362

Vij S, Tyagi AK (2006) Genome-wide analysis of the stress associated protein (SAP) gene family containing A20/AN1 zinc-finger(s) in rice and their phylogenetic relationship with Arabidopsis. Mol Genet Genomics 276:565-575

Vij S, Gupta V, Kumar D, Vydianathan R, Raghuvanshi S, Khurana P, Khurana JP, Tyagi AK (2006) Decoding the rice genome. Bioessays 28:421-432

Vij S, Giri J, Dansana PK, Kapoor S, Tyagi AK (2008) The receptor-like cytoplasmic kinase (OsRLCK) gene family in rice: organization, phylogenetic relationship, and expression during development and stress. Mol Plant 1:732-750

Vijayan J, Devanna BN, Singh NK, Sharma TR (2015) Cloning and functional validation of early inducible Magnaporthe oryzae responsive CYP76M7 promoter from rice. Front Plant Sci 6:371

Vikram P, Swamy BP, Dixit S, Ahmed HU, Teresa Sta Cruz M, Singh AK, Kumar A (2011) qDTY 1.1, a major QTL for rice grain yield under reproductive-stage drought stress with a consistent effect in multiple elite genetic backgrounds. BMC Genet 12:89

Wang M, Yu Y, Haberer G, Marri PR, Fan C, Goicoechea JL, Zuccolo A, Song X, Kudrna D, Ammiraju JS, Cossu RM, Maldonado C, Chen J, Lee S, Sisneros N, de Baynast K, Golser W, Wissotski M, Kim W, Sanchez P, Ndjiondjop MN, Sanni K, Long M, Carney J, Panaud O, Wicker T, Machado CA, Chen M, Mayer KF, Rounsley S, Wing RA (2014) The genome sequence of African rice (Oryza glaberrima) and evidence for independent domestication. Nat Genet 46:982-988

Wankhede DP, Kumar K, Singh P, Sinha AK (2013) Involvement of mitogen activated protein kinase kinase 6 in UV induced transcripts accumulation of genes in phytoalexin biosynthesis in rice. Rice 6:35

\section{Submit your manuscript to a SpringerOpen ${ }^{\circ}$ journal and benefit from:}

- Convenient online submission

- Rigorous peer review

- Immediate publication on acceptance

- Open access: articles freely available online

- High visibility within the field

- Retaining the copyright to your article

Submit your next manuscript at $\boldsymbol{s p r i n g e r o p e n . c o m ~}$ 